\title{
"Shooting Characters": A Phonological Game and Its Uses in Late Imperial China
}

\author{
MÅRTEN SÖDERBLOM SAARELA \\ Max Planck Institute For the History of Science, Berlin
}

\begin{abstract}
“Shooting [or 'guessing'] characters" (shèzì 射字) was a game, and later a communication method, based on phonological analysis of Chinese syllables. Over time, it became used in a variety of ways, including as a teaching tool, a cipher, and a phonological writing aid for the less educated. The actual and proposed applications of one phonological game show that Chinese phonology did not just exist in books, but encompassed distinct non-written practices that were essential to its proliferation. Chinese phonology is generally studied as a source for the history of the Chinese language, but it is also of interest for the history of cultural and intellectual life.
\end{abstract}

The phonological communication method that originated as the game of "shooting [or 'guessing'] characters" (shèzì 射字), which used numbers to communicate elements of language according to their pronunciation, was widespread in late imperial China and known under several names. Its ubiquity inspired writers to generalize it as the paradigmatic instance of communicating without speaking or writing. Neo-Confucian philosopher, administrator, and student of Western astronomy Lù Lǒngqí 陸隴其 (1630-1693, or Hè Yǔfēng 賀雨峯, creator of the extant manuscript ascribed to Lù and dating from after 1716), ${ }^{1}$ called it the “method of knocking syllables" (qiāoyīn fă 敲音法) and inferred its presence in a story of communication through music related in the Confucian Analects:

This [method] is what Confucius, the sage, employed when he was playing the stone chimes in

Wèi and a man with a straw basket heard it and understood his frustrated purpose.

此所以孔聖在衛借擊馨以敲音, 荷貴聞之而知其心事也。2

It was not just Confucius who allegedly communicated in this way. Hú Yín 胡意 (fl. 1906), who called the method by a different, common name (that I will discuss presently), saw in it the principles of the telegraph:

I presented a draft of this paper at the Association for Asian Studies Annual Conference (Seattle, March 31-April 3, 2016), where I talked about it with fellow panelists Emi Foulk, Si Nae Park, Nathan Vedal, our discussant David Lurie, and members of the audience. Vedal, Wolfgang Behr (who also shared unpublished material with me), Richard VanNess Simmons, Stéphanie Homola, and Michael Stanley-Baker read and commented on different versions. Marta Hanson and Han Zhang provided references, La Źieng-Kiet (Lo Sheng-gi) shared inaccessible scholarship from Taiwan, and one of the anonymous reviewers offered detailed remarks. I am grateful to all of them for their help, which led to substantial improvement of the paper.

1. Chaoying Fang, "Lu Lung-chi [sic, read: ch'i]," in Eminent Chinese of the Ch'ing Period (1644-1912), ed. Arthur W. Hummel, vol. 1 (Washington: United States Government Printing Office, 1944), 547-48; John B. Henderson, “Ch'ing Scholars' Views of Western Astronomy," Harvard Journal of Asiatic Studies 46 (1986): 122.

2. Lù Lǒngqí and Hè Yǔfēng, "Děngyùn biàndú” 等韻便讀, in Hănjiàn yùnshū cóngbiān, vol. 1, facsimile of undated chirograph referencing (on p. 731) a work that appeared in 1716 (Kāngxī zìdiăn 康熙字典) (Hong Kong: Chángchéng wénhuà chūbăn gōngsī, 1995), 732. The reference is to Confucius, The Analects, tr. D. C. Lau (London: Penguin, 1979), 14:39. 
Westerners use wires carrying electrical current to manipulate the movement of a compass needle and then observe what letters $(m \breve{u})$ the needle indicates, and merge them to form words $(z i)$. Communication is thereby possible instantly, even across mountains or the vast expanses of the oceans. What they are using is precisely this method [of "shooting characters"].

西洋人用電氣發增減線, 以轉吸鐵指南鍼, 觀其所指何母, 湊合成字。雖越山, 渡海千萬 里外, 瞬息可通。即用此法也。3

What apparently originated as a game had, by the turn of the twentieth century, become identified with the communications technology of nineteenth-century industrialism. During its documented history of almost a millennium, the game of "shooting characters" was used in several different contexts and discussed in several more. In this paper, I will discuss the game from its earliest mentions in the thirteenth century to the first years of the twentieth, with a focus on the last centuries of imperial rule, from which most of my sources date. I will treat the game's relationship to the discipline of phonology, situate it within Chinese literati culture, survey its proposed usage as a cipher for secret letters or military communications, and finally consider its role as the indirect inspiration for a phonological writing aid for the less educated. Taken together, these actual and proposed applications of one phonological game show that Chinese phonology did not just exist in books, but encompassed distinct non-written practices that were essential to its proliferation. Widely applied in a variety of ludic, pedagogical, scholarly, and esoteric contexts, the study of Chinese phonology is of interest not only for the development of the language itself, but also for the history of cultural and intellectual life.

\section{THE GAME'S PHONOLOGICAL PREREQUISITES}

The game of "shooting characters," which commuted syllables to numbers, was comparable to some forms of language play in the European Renaissance. ${ }^{4}$ It coexisted in China with games and riddles based on the structure of the script, which, like "shooting characters," were used to write encoded messages. ${ }^{5}$ Its closest relatives, however, were arguably the drinking games so common in the late imperial period, as they, like "shooting characters," contained an element of competition and were based on "guessing" (another meaning of shè). ${ }^{6}$

3. Hú Yín 胡夤, Qièyīn qǔméng 切音啓蒙, facsimile of xylograph, in Cóngshū jíchéng xùbiān, vol. 75, written before 1906 (1940; Táiběi: Xīn fēng chūbǎngōngsī, 1989), 7b.

4. Claude-Gilbert Dubois, "L'invention littéraire et les jeux du langage: Jeux de nombres, jeux de sons, jeux de sens," in Les jeux à la Renaissance, ed. Philippe Ariès and Jean-Claude Margolin (Paris: J. Vrin, 1982), $245-69$.

5. Wolfgang Behr, "In the Interstices of Representation: Ludic Writing and the Locus of Polysemy in the Chinese Sign," in The Idea of Writing: Play and Complexity, ed. Alex de Voogt and Irving Finkel (Leiden: Brill, 2010), 281-314.

6. On drinking games, see Yuming He, Home and the World: Editing the "Glorious Ming" in WoodblockPrinted Books of the Sixteenth and Seventeenth Centuries (Cambridge, Mass.: Harvard-Yenching Institute, 2013), 48 and 184-85; Andrea Bréard, "Knowledge and Practice of Mathematics in Late Ming Daily Life Encyclopedias," in Looking at It from Asia: The Processes that Shaped the Sources of History of Science, ed. Florence BretelleEstablet (Dordrecht: Springer, 2010), 322; Andrea Bréard, "Usages et destins des savoirs mathématiques dans les Encyclopédies aux dix mille trésors des Ming," in "Pratiques lettrées au Japon et en Chine: XVIIe-XIXe siècle," ed. Annick Horiuchi and Daniel Struve, Études Japonaises 5 (2010): 108-10. On the meaning of the verb shè "to shoot" in the sense of "to guess" in such games, see Chén Xīn 陈新, "Yuèdú Hónglóu huà "shèfû"” 阅读 《红楼》 话「射覆」, Yuèdú yǔ xiězuò, no. 5 (1999): 38-39; Cáo Xuěqín 曹雪芹, Hónglóu mèng: Bāshí huì shítóu jì 红楼 梦：八十回石头记, typeset edition, ed. Zhōu Rǔchāng, 2 vols., written in the eighteenth century (Běijīng: Rénmín chūbănshè, 2006), vol. 2, ch. 62, 638; Cao Xueqin, The Story of the Stone, tr. David Hawkes, vol. 3 (1980; London: Penguin, 1987), 196 (where the name of the game in question is translated as "cover-ups"). 
The game relied on a series of inventions in Chinese poetics and phonological lexicography. The basis of "shooting characters" was the segmentation of the Chinese syllable into a number of phonological properties and their subsequent arrangement in serial sequences according to those properties. These two related inventions appeared centuries before the earliest documented appearance of the game.

The segmentation of the syllable happened through a series of discoveries. In the fourth century CE, theoreticians of poetry identified a number of pitch tones (see figure 1) among Chinese syllables. ${ }^{7}$ At some point, the Chinese syllable was further divided into the two parts of initial (traditionally [zì]mǔ [字]母, "[syllabic] productive elements," 8 now called shēngmǔ 聲母) and final (now called yùnmй 韻母). It has been proposed that the analysis of the syllable into two parts might have originated in popular language games, only later making its way into books. ${ }^{9}$ Whatever the case, the division of the syllable dates to before the seventh century CE, as dictionaries, "rhyme books" (yùnshü 韻書), from that period make use of it. The segmentation of the syllable was carried out by spelling it using two other syllables. The first of the two spelling syllables shared an initial consonant (sometimes accompanied by a glide) or zero onset with the spelled syllable, and the second shared the rhyme, which included the main vowel, possibly a stop or nasal consonant, an off-glide, or, functionally speaking, a zero final if there was no consonant, and one of the morphemic pitch tones. Using the method, called fănqiè 反切, for the modern standard language, we can spell xiān 先 as $x(\bar{u})$ 虛 plus $(q) i \bar{a} n$ 謙.

In rhyme books, syllables were arranged in sequences on the basis of these segmentations. The influential Guăngyùn 廣韻 (The expanded rhymes; eleventh century), ${ }^{10}$ following earlier precedents not generally available to later scholars, separated tone from rhyme in a twolayered arrangement consisting first of a sequence of tones that, in turn, organized sequences of rhymes. The sequence of rhymes naturally had a relationship to the phonology of the spoken language. As Chinese speech varied over time and between places, the sequence of rhymes that scholars included in rhyme books varied as well. However, since the literary genre of regularized verse (lüshī 律詩) became, as it name indicates, a fixed form, many rhyme books reproduced roughly the same sequence of organizing rhymes, allowing readers to use it as a reference work for writing poetry. Common rhyme books in this tradition used a sequence of around one to more than two hundred rhymes.

The initials, the existence of which was implied in the fănqiè operation, were also used to arrange syllables in sequences. At least by the eighth century $\mathrm{CE}$, scholars had identified a detailed repertoire of initials occurring in Chinese syllables. ${ }^{11}$ In the most widespread version, they numbered thirty-six, but writers of later periods often reduced this number to better reflect some variant of the language as spoken in their own day.

7. Victor H. Mair and Tsu-lin Mei, "The Sanskrit Origins of Recent Style Prosody," Harvard Journal of Asiatic Studies 51 (1991): 375-470.

8. W. South Coblin, "Zhāng Línzhī on the Yùnjìng," in The Chinese Rime Tables: Linguistic Philosophy and Historical-Comparative Phonology, ed. David Prager Branner (Amsterdam: John Benjamins, 2006), 128.

9. Yuen-ren Chao [Zhào Yuánrèn 趙元任], “Fănqiè yǔ bā zhǒng” 反切語八種, Zhōngyāng yánjiū yuàn lìsh yǔyán yánjiūsuǒ jiḱān 2, no. 3 (1931): 318.

10. Yú Năiyǒng 余迺永, ed., Xīn jiào hùzhù Sòng-běn “Guăngyùn” 新校互註宋本廣韻 (Shànghăi: Shànghăi císhū chūbănshè, 1993).

11. David Prager Branner, "The Establishment of the Chinese Linguistic Tradition," in History of the Language Sciences / Geschichte der Sprachwissenschaften / Histoire des sciences du langage, ed. Sylvain Auroux et al., vol. 1 (Berlin: Walter de Gruyter, 2000), 50; W. South Coblin, "Reflections on the Shǒuwēn Fragments," in Branner, The Chinese Rime Tables, 99-122. 


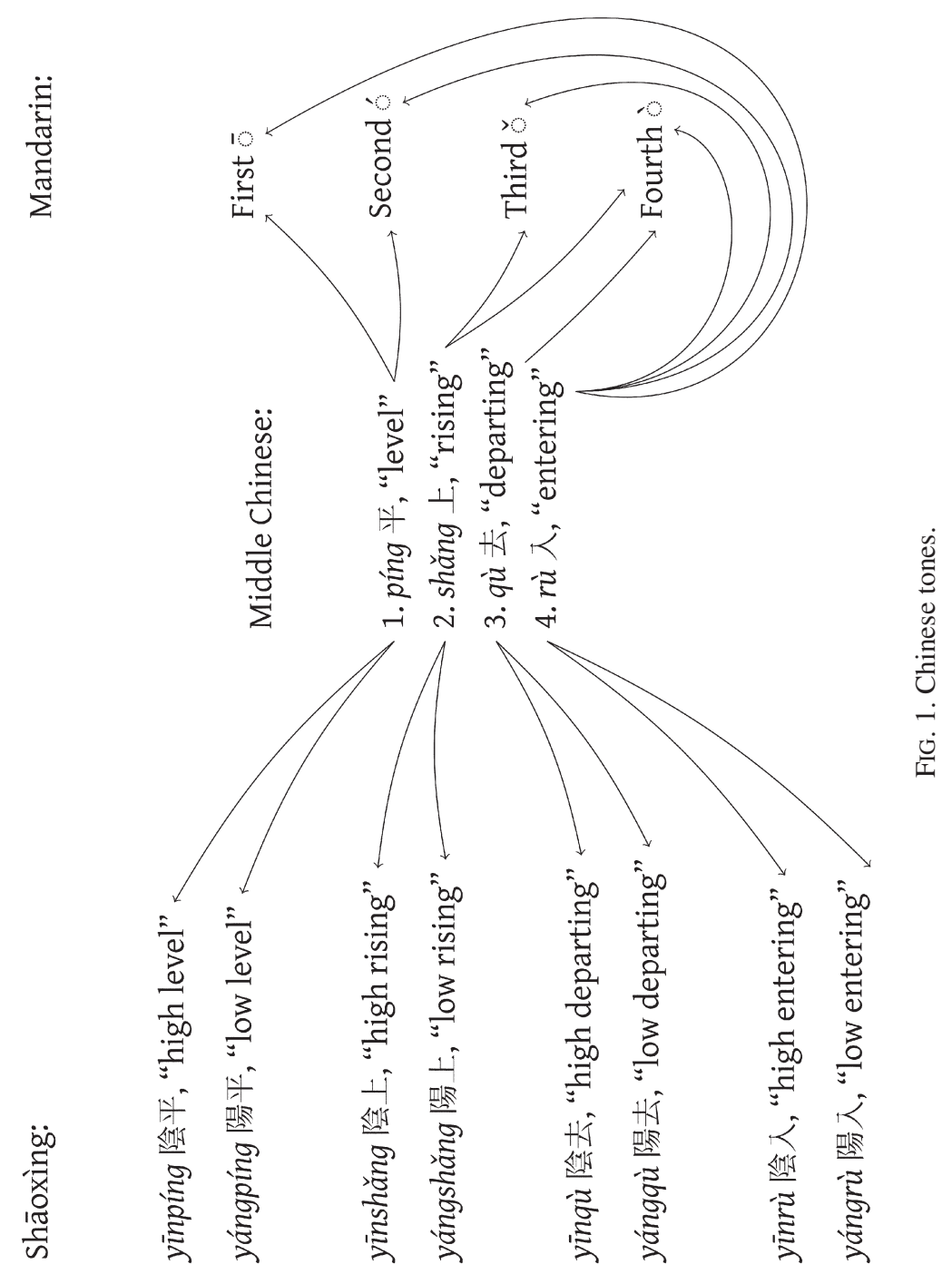


When the game of "shooting characters" was recorded in the thirteenth century, a new tool of analysis, the graded rhyme table (děngyùn tú 等韻圖), had been integrated to the mainstream of Chinese phonology for two hundred years. "Shooting characters" was related to the memorization of sequences from phonological dictionaries in order to facilitate the writing of regularized verse. The graded rhyme tables were probably largely used as a tool to navigate those same dictionaries. By the time of the tables' rise to popularity in the twelfth century, the dictionaries were several hundred years old and represented Chinese pronunciations that were no longer current in the spoken language, making them difficult to use. ${ }^{12} \mathrm{I}$ will use Edwin G. Pulleyblank's (1922-2013) Late Middle Chinese (LMC) reconstructions to represent the language of the twelfth-century rhyme tables. ${ }^{13}$

The most basic feature of a graded rhyme table was its use of two dimensions. Rather than listing syllables with similar phonological properties in sequences that followed one after the other in a series, the tables used two sequences as the axes of a grid, in which each cell represented a syllable that obtained one property from each axis. The axes commonly contained sequences of initials, rhymes, tones, and the like. It is not obvious that the game of "shooting characters" in its earliest attested incarnation was inspired by the graded rhyme tables, but the use of the sequence of initials suggests it was.

The whole sound system represented in a rhyme book could not easily be made to fit into a single table. Rather, books of tables often contained a number of them, each one listing a smaller set of similar-sounding syllables such as, for example, those included in one of the rhymes of the Guăngyùn. If the tables had the same layout, syllables belonging to different rhymes but sharing other phonological properties would appear in the same position in their respective table. Zhāng Línzhī 張麟之 (fl. c. 1130-1203), in the introduction to the table Yùnjìng 韻鏡 (Mirror of rhymes; extant version dating from 1197-98 with a preface dated 1161), described the advantages that this table structure had for resolving fănqiè spellings: the actual comparing of pronounced syllables could be partially circumvented by moving between corresponding positions in the tables. ${ }^{14}$ Later scholars saw in this aspect a similarity to "shooting characters."

\section{EARLIEST MENTIONS OF THE GAME AS PUBLIC ENTERTAINMENT}

The earliest evidence of "shooting characters" dates from long after the isolation of initial, rhyme, and tone in lexicography and poetics. The game's earliest mention is found in a collection of jottings dating from 1219-24. Its author, Zhào Yǔshí 趙與岶 (conventionally 11751232), ${ }^{15}$ described it as "a stunt, found among the popular practices, called 'striking the drum to shoot [guess] characters” ” 俗閒有擊鼓射字之伎, adding that it was of unknown origin. ${ }^{16}$

The game used two stanzas of regularized heptasyllabic verse (qìyán 七言), ${ }^{17}$ transcribed in LMC in table $1 .{ }^{18}$ The two stanzas of the poem contained syllables that represented the

12. Coblin, "Reflections on the Shǒuwēn Fragments," 121-22.

13. I am aware of the controversy surrounding Pulleyblank's approach to Chinese historical linguistics. See Pulleyblank, "Qieyun and Yunjing: The Essential Foundation for Chinese Historical Linguistics," JAOS 118 (1998): 200-216; Branner, "Introduction," in The Chinese Rime Tables, 13-14.

14. Yùnjìng jiàozhèng 韻鏡校證, facsimile of xylograph, ed. Lǐ Xīnkuí, preface dated 1161 (Běijīng: Zhōnghuá shūjú, 1982), 5b (20); Coblin, "Zhāng Línzhī on the Yùnjìng," 135 (para. 3.5) and 143-44.

15. Cf. Chén Wěiwén 陈伟文, “Bīn tuì lù zuòzhě Zhào Yǔshí kǎo” 《宾退录》作者赵与岶考, Wénxiàn, no. 4 (2011): 188-92.

16. Zhào Yǔshí, Bīntuì lù 賓退錄, critical edition, ed. Jiāng Hànchūn, in Quán Sòng bǔjì 6, vol. 10, written during 1219-24 (Zhèngzhōu: Dàxiàng chùbănshè, 2013), ch. 1, 12.

17. This kind of verse is described in Wáng Lì 王力, Hànyǔ shïlù xué 汉语诗律学, vol. 14, bk. 1 of Wáng Lì wénjí, finished in manuscript in 1947 (1957; Jìnán: Shāndōng jiàoyù chūbănshè, 1984-1991), ch. 1, sec. 19.

18. My discussion of the poem is a summary of the findings in Masamura Kenpei 将邑剑平 and Hirayama Hisao 平山久雄, “Bīntù̀ lù shèzì shī de yīnyùn fēnxī” 《宾退录》射字诗的音韵分析, Zhōngguó yǔwén, no. 4 
initials and finals of the current language, in six and seven lines respectively, totaling ninetyone syllables and representing thirty-two initials (of which ten could have either a palatalized or an unpalatalized pronunciation) and fifty-three non-stop finals. The poem did not list the stop (or entering tone) finals, even though they existed in the language of the time.

To accentuate the differences between the syllables in the first stanza, which represented the initials, the finals of those syllables were very similar, having unrounded vowels (kāikǒu 開口). ${ }^{19}$ It is possible that the vowel was $-i$ or, after certain initials, $-l$ (LMC: $z$ ) in all of the syllables. If so, they would have sounded more alike than what appears from the LMC transcriptions in table $1 .{ }^{20}$ This characteristic also made the stanza "easy to recite and practice" (biàn yú sǒngxí 便於誦習), which was further facilitated by the poem's tendency to group initials according to whether they were accompanied by voiced aspiration (zhuó 濁; marked in the LMC transcription with $h$ ), seen in the third and fourth lines of the first stanza in the poem as recorded by Zhào. ${ }^{21}$ Similarly, the syllables were all in the level tone, a similarity that foregrounded the differences. Furthermore, some characters seem to have been placed where we find them in order to make the list of initials appear more like a regular poem, so as to be easier to memorize. All characters appear to have been lifted from Guăngyùn. ${ }^{22}$

The second stanza is reproduced in table 2. Three fourths of its syllables have the initials $k$ - 見 or $l$ - 來. It appears that only when there was no appropriate character with an $l$-initial did the author of the poem choose one with $k$-, perhaps because $l$ - initial syllables were euphonic and often represented frequently used words.

As shown in table 1, the poem was perhaps originally ordered differently from what we see in Zhào Yǔshí's collection of jottings. It makes little sense to try to translate it; its purpose was only ever to display phonological features.

In addition to the poem, the game also made use of a four-syllable sequence representing the tones of Middle Chinese.

The game that Zhào described demanded two players. Player A produced a series of drum rolls. The number of beats in the rolls represented, in turn, (1) a line in the poem's first stanza (one to six beats); (2) one syllable within that line (one to seven beats); (3) a line in the second stanza (one to seven beats); (4) one syllable within that line (one to seven beats); (5) one syllable in the sequence representing tones (one to four beats). Rolls 1 and 2 indicated the initial, rolls 3 and 4 the rhyme, and roll 5 the tone of a Chinese syllable. Player B had to piece together the syllable from that information. It is possible that the creator of the game followed Guăngyùn in assuming an association of the entering-tone syllables, which had stop finals, with homorganic nasal-final syllables of the level tone; if the number of the fifth roll was four, player B was probably expected to substitute the syllable indicated through third and fourth rolls for one with the appropriate stop final. Success in the game depended on player B having mastered the fănqiè method for spelling syllables and having memorized the two stanzas of the poem and the sequence of the four tones.

(1999): 295-303. If there is no indication otherwise, their paper is the source of all statements relating to the poem in the following paragraphs.

19. Branner, "Introduction," 18 for the term kāikǒu.

20. The sound system represented in the poem is close to that in the graded rhyme table Qièyùn zhǔzhăng tú 切韻指掌圖 (Hand diagram for spelling rhymes; extant edition printed in 1230), which probably represents a later form of Chinese than the LMC transcription that I give here. On this rhyme table and its language, see Sòngběn Qièyùn zhǔzhăng tú 宋本切韻指掌圖, facsimile of xylograph (1230; Běijīng: Zhōnghuá shūjú, 1986); Coblin, "Zhāng Línzhī on the Yùnjìng," 124-25; Branner, "Introduction," 15.

21. Edwin G. Pulleyblank, "Late Middle Chinese," Asia Major 15.2 (1970): 211-12.

22. Zhōu Zǔmó 周祖謨, “Shèzì fă yǔ yīnyùn” 射字法與音韻, in Wènxué jí, vol. 2 (Běijīng: Zhōnghuá shūjú, 1966), 665 


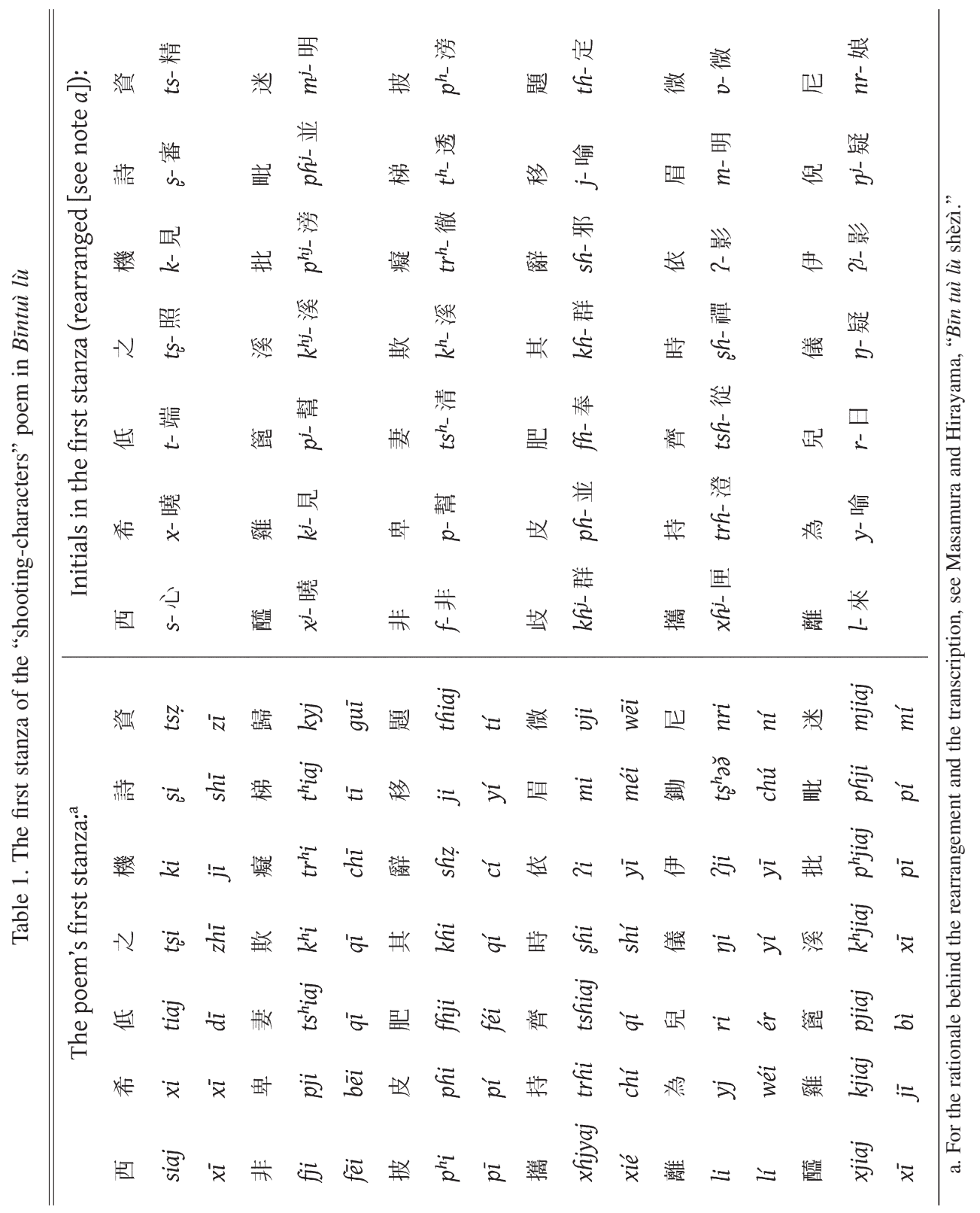


Table 2. The second stanza of the "shooting-characters" poem in Bīntuì lì

\begin{tabular}{|c|c|c|c|c|c|c|}
\hline 羅 & 家 & 瓜 & 藍 & 斜 & 凌 & 倫 \\
\hline la & kja: & $k w a:$ & lam & shia & liăy & lyn \\
\hline luó & $j i \bar{a}$ & $g u \bar{a}$ & lán & xié & ling & lún \\
\hline 思 & 戈 & 交 & 勞 & 皆 & 來 & 論 \\
\hline$s z$ & kua & kja:w & law & kjarj & laj & lun \\
\hline$s \bar{l}$ & gé & jiāo & láo & $j i \bar{e}$ & lái & lún \\
\hline 留 & 連 & 王 & 郎 & 龍 & 南 & 關 \\
\hline liw & lian & yay & lay & lywy & nam & kwain \\
\hline liú & lián & wáng & láng & lóng & nán & guān \\
\hline 盧 & 廿 & 林 & 巒 & 雷 & 聊 & 鄰 \\
\hline luă & kam & $\mathrm{lim}$ & luan & luaj & liaw & $\operatorname{lin}$ \\
\hline lú & $g \bar{a} n$ & lin & luán & léi & liáo & lín \\
\hline 簾 & 㯙 & 崩 & 婁 & 參 & 辰 & 闌 \\
\hline liam & lawn & jiajp & low & $t s^{h} a m$ & shin & lan \\
\hline lián & lóng & yíng & lóu & cān & chén & lán \\
\hline 楞 & 根 & 彎 & 雛 & 驢 & 寒 & 閒 \\
\hline ləăy & kan & ?wain & tşhuă & liă & xhan & xfja:n \\
\hline léng & gèn & $w \bar{a} n$ & chú & liú & hán & xián \\
\hline 懷 & 横 & 榮 & 鞋 & 庚 & 光 & 顏 \\
\hline$x h w a \cdot j$ & $x$ fwwaijn & yajy & $x$ hijaij & kjaijy & kuay & njain \\
\hline huái & héng & róng & xié & gēng & guāng & yán \\
\hline
\end{tabular}

To communicate the spelling of $t \partial w \eta_{1}$ 東 (dong; the subscripted numeral represents the first of the four tones, the level tone) using the rules described by Zhào, player A would first beat the drum once, and then pause. Player B would thereby know that the first fănqiè speller, indicating the initial of the spelled syllable, was to be found in the first line of the poem's first stanza. Second, player A would beat the drum three times. Player B would then know that the first speller was tiaj 低 $(d \bar{\imath})$. Third, player A would give five beats, leading player B to the fifth line in the second stanza, where the second speller would be found. Fourth, player A would beat the drum twice, indicating that the second speller was lawn 㯙 (lóng). Fifth and finally, player A would give one beat to indicate the first tone out of four. Player B could then put $t(i a j)+(l) \partial w \eta+1$ together and form $t \partial w \eta_{1}$. Big cheers from the audience, one might imagine, would ensue. Had the number of the fifth roll been four, indicating an entering-tone syllable, player B would probably have been expected to exchange the third and fourth rolls' law for Powk 屋, ${ }^{23}$ which would yield the entering-tone syllable towk 督.

Following the description of "shooting characters," Zhào mentioned a drinking game involving lines of poetry and a technique used by professional fortunetellers (màibŭ 賣卜)

23. Dīng Shēngshù 丁聲樹 and Lǐ Róng 李榮, “Hànyǔ yīnyùn jiăngyì” 漢語音韻講義, Fāngyán, no. 4 (1981): 251 (table 4) shows that ?awk $(w \bar{u})$ 屋 represented the entering-tone rhyme corresponding to the level-tone rhyme təwy (dōng) 東 in the Guăngyùn tradition. 
that featured an individual's birth date expressed using the sexagenary cycle and the beating of a drum. Zhào found these activities similar to "shooting characters," perhaps because they involved the memorization of series of monosyllables. ${ }^{24}$

\section{THE GAME AS A LITERATI PASTIME}

Presumably, mostly classically literate individuals, who engaged in the highbrow activity of writing regular verse, would compete successfully in the "popular" game that Zhào Yǔshí described. However, the use of a such a loud instrument as a drum in Zhào's account suggests that the game was played in front of an audience, perhaps in a marketplace, at a temple fair-both places where a mixed crowd would gather-or at least at a large dinner party. Yet Zhào wrote that the flipping of a fan (huīshàn 揮扇) could replace the drum rolls, ${ }^{25}$ which allowed for a more intimate setting for the game and more polite company. Táo Zōngyí 陶 宗儀, writing in the fourteenth century, described the game in such a setting: "If one uses hand claps instead of drum rolls, one can avoid the popular ambiance of the market place and [city] well” 用拊掌代擊鼓, 殊無勾肆市井俗態. In times of leisure, one could play the game “for a moment's laughter and merriment” 以取一時之笑樂耳. ${ }^{26}$

Other descriptions similarly departed from urban entertainment, with one early nineteenth-century source adding “tapping on the table or knocking on a cup” 或拍案, 或敲杯 as character-shooting methods. ${ }^{27}$ Knocking was a popular method. Lù Lǒngqí, quoted at the opening of this paper, used "knocking syllables" to refer to the game as a whole, and he was not the only one. ${ }^{28}$ Hú Yuán 胡垣 (fl. 1846-1888) in the late nineteenth century described a method that combined handclaps ([shǒu]pāi [手]拍) and finger taps ([zhǔ]diăn [指]點). By clapping his hands, player A, in Hú's version, moved through the lines (jù 句). Once arrived at the right line, he indicated the syllable within that line through finger taps. ${ }^{29}$

The poet Yuán Méi 袁枚 (1716-1798) promoted a kind of stunt in some respects similar to the phonological game in its literati inception. He recommended the stunt to one of his correspondents using the example of poet and calligrapher Zhōu Jǔ 周智 (literary name Màntíng 幔亭; 1712-1779): ${ }^{30}$

What was even more marvelous was [Zhōu's] stunt of transmitting sounds. When someone arrived at his house, guest and host would sit down facing each other without making a sound. If the guest wanted something, Zhōu would just use the shaft of his writing brush to tap a few, or a dozen, times against a bowl, and hot tea and rice cakes would be brought from inside the house [by a servant who knew the stunt and heard the taps]. Zhōu used a bowl instead of his mouth, and he never got it wrong! ... When he went outdoors, he would bring the servant with him, and wherever they went, they would demonstrate the stunt. Why don't you try it out and then teach it to the members of your household?

24. Zhào, Bīntuì lù, ch. 1, 12.

25. Ibid.

26. Táo Zōngyí, Náncūn chuògēng lù 南村輟耕錄, in Sìbù cóngkān 3, vol. 56, facsimile of xylograph (1366; Shànghăi: Shànghăi shūdiàn, 1985), 19:10b-11a.

27. Xú Jiàn 徐鑑, Yīnfü 音泭, Xùxīu “Sìkù quánshū": jīngbù, vol. 258, facsimile of xylograph (1817; Shànghăi: Shànghăi gǔjí chūbănshè, 1995), 3a.

28. E.g., "transmitting sound by striking or knocking” 擊敲傳響, see Zhāng Xùbīn 張序賓, Shēngyùn zhǔzhăng 聲韻指掌, in Hănjiàn yùnshū cóngbiān, vol. 2, facsimile of undated chirograph originating in the Qīng Hànlín Academy, 1296.

29. Hú Yuán, Gǔ-jīn, Zhōng-wài yīnyùn tōnglì 古今中外音韻通例, xylograph, 4 vols., preface dated 1886 (1888), held at Taiwan Normal Univ. Library (call number A 940 313), vol. 4, chuánshēng:4a.

30. Xú Yàn 徐雁 and Wáng Yúguāng 王余光, Zhōngguó dúshū dà cídiăn 中国读书大辞典 (Nánjīng: Nánjīng Dàxué chūbănshè, 1999), 56. 
更妙者能為傳響之伎。嘗至其家, 主人對坐,噤不發聲, 客有所需, 但取筆管吒盎二三或十 數響, 則茶湯粉饂, 悉從内出。借盎代口, 百無一差 ...渠出外則以一奴自隨, 到處可 以奏伎。足下何不進而試之, 且令家人學之邪? ${ }^{31}$

The phonologist Xú Jiàn 徐鑑 (fl. 1817) believed that Méi was describing the "game” (xì 戲) of "shooting characters," 32 but what was going on between Zhōu and his servant might just as well have been a simpler arrangement that was not, properly speaking, phonological. Zhōu could have taught his servant a list of monosyllabic words, among which "tea" (chá) and "cake" (е̌r r) figured, perhaps arranged in way that made them easy to remember. Success in the endeavor would have depended on the servant's ability to memorize the sequence and follow along in pace with the taps. Hú Yuán described a practice associated with "shooting characters" that functioned similarly. A speaker would pronounce syllables from a sequence that the listener had memorized, stopping before the intended syllable. The listener, who knew what syllable would have followed, thereby also knew what the speaker meant to say without the word being pronounced. ${ }^{33}$ Zhōu's version as related by Yuán, however, was even less of a game than this means of secret communication; the merriment it aroused in Zhōu's guests and neighbors seems to have been largely at the expense of the poor servant, whom Zhōu ordered around with the simple tap of a brush shaft.

Zhōu Jǔ's stunt has an unclear relationship to the game of "shooting characters" proper. Yet even among the more closely related variants that were based on representing syllables using numbers for their phonological properties there was great variation. The basic principle remained the same, but the number of sequences used, their order, and their contents differed substantially. One undated pedagogical manuscript, for instance, presented a variant in which the tone was given after the rhyme and before the initial. ${ }^{34}$ In other versions, rhyme preceded initial. ${ }^{35}$ An aspiring player had to be aware of such variation: "Whenever a number of people play the game of shooting characters together, it occurs that some know one [variant] but not another, while others know only the other [variant]" 數人互為射字之 戲, 有此知而彼不知, 彼知而此不知者. ${ }^{36}$

The “phonological game" 音韻之遊戲 became so well known that one book expressly written toward the mid-nineteenth century to facilitate it could forego actually explaining how it was played. ${ }^{37}$ The game was widespread throughout the late imperial period. Indeed,

31. Yuán Méi, “Xiǎocāng Shān fáng chǐdú” 小倉山房尺牘, in Yuán Méi quánjí, typeset edition, ed. Wáng Yīngzhì, vol. 5, first printed before 1791 (Nánjīng: Jiāngsū gǔjí chūbănshè, 1993), 26 (ch. 1).

32. Xú, Yīnfū, [yúlùn:]21b.

33. Hú, Gü-jīn, Zhōng-wài yīnyùn tōnglì, vol. 4, chuánshēng:1b-2a.

34. Fānqiè zhǔzhăng, kōnggǔ chuánshēng 翻切指掌空谷傳聲, in Hănjiàn yùnshū cóngbiān, vol. 2, facsimile of undated chirograph, 1520 and 1522.

35. E.g., Gāo Wěngyìng 高奛映, ed., “Děngyīn,” “Shêngwèi” héhuì 等音聲位合彙, facsimile of xylograph, by Mă Ziyuán 馬自援 and Lín Běnyù 林本裕, in Cóngshū jíchéng xùbiān, vol. 75, undated, but originally printed in 1702-03 (1914), xià:81b-85a (488-90); Méi Jiàn 梅建, reviser, Chóngdìng Măshì děngyīn 重訂馬氏等音, by Mă Ziyuán, 2 vols., xylograph (1708), held at Harvard-Yenching Library (call number T 5127 4514), vol. 1, chuánxiăng shèzì fă:34a-b; Qú Wànjiàn 璩萬鑑, ed., Děngyīn xīnjí èr biān 等音新集二編, by Shùshèng Zhāi zhǔrén 述聖齋主人, 2 vols., xylograph (1760), held at Taiwan Normal Univ. Library (call number A 940 856), vol. 2, hòubiān:33a-35. For a similar version of the game, see Yúshì jiéyùn 于氏捷韻, in Hănjiàn yùnshū cóngbiān, vol. 2, facsimile of undated chirograph, 1266.

36. Lǐ Rúzhēn 李汝珍, Lǐshì yīnjiàn 李氏音鑑, 4 vols., xylograph (1805; Guīyè shānfáng, 1888), held at Taiwan Normal Univ. Library (call number a 940 161.1), 5:14a.

37. Xǐ-ēn 禧恩 (d. 1852) in Yù-ēn 裕恩, Yīnyùn féngyuán 音韻逢源, ed. Xǐ-ēn, in Xùxiū “Sìkù quánshū": jīngbù, vol. 258, facsimile of xylograph (1840), 4a. 
according to Mǎ Ziyuán 馬自援 (courtesy name Pánshí 槃什; fl. mid-to-late seventeenth century), ${ }^{38}$ in order to play it, "the student only has to commit to learning a hundred and some dozen characters by rote, which can be done in a couple of days” 學者用心苦記, 功夫不過百十餘字, 故一二日即可全會. ${ }^{39}$ This would have been a small task for anyone having undergone a Chinese curriculum.

\section{THE GAME AND PHONOLOGICAL TRAINING}

In the late imperial period and into the twentieth century, the spelling of syllables in fănqiè-like fashion was widespread in many communities (including among school children, blind fortunetellers, the urban underworld, and, evidently, writers of literature), where it was used as a game or secret language, sometimes without recourse to writing. ${ }^{40}$ At least some of these games descended from written predecessors, as they still involved memorizing alliterating or rhyming lines of text that represented the language's initials and finals. ${ }^{41}$ Elementary phonological knowledge of a more bookish kind was probably also relatively common throughout the period, as it was useful for writing and reading poetry, acquiring prestigious pronunciations, or making sense of old or obscure texts. The devil, however, was in the detail: Mă Ziyuán claimed that "not even the most intelligent person will have mastered all the difficulties [of phonology] after a whole year [of study]” 最聰敏者尚有終年不會之難. ${ }^{42}$

Memorizing sequences of syllables chosen for their phonological properties was a cornerstone of phonological training. The basics of phonology, the idea that a syllable could be described as a cluster of a finite number of characteristics, were instilled in the students by osmosis. Repeatedly reading, reciting, and recalling the sequences of syllables that represented initials and rhymes, and thus actually constituted the final product of the phonological analysis, were thought to eventually cause an epiphany in the students, by which they would understand how the analysis had been effectuated. Whether the students always experienced such an epiphany, or managed to carry out phonological operations anyway, is an open question. Indeed, the understanding of phonological analysis among late imperial practitioners was one of the issues brought up during the review of this paper. I will return to it presently.

When learning phonology, students were asked to memorize sequences of syllables exhibiting differences in one property (e.g., initial, final, or tone). When faced with a syllable that they wanted to subject to phonological analysis, they would run through the sequences until

38. Chí Tǐngqīn 池挺钦, “Děngyīn bănběn yánjiū: Jiān xī Děngyīn zhōng de chóngchū zì” 《等音》版本研 究: 兼析《等音》中的重出字, Húběi Jīngjì Xuéyuàn xuébào (rénwén shèhuì kēxué băn) 4, no. 9 (2007): 146. Mă Ziyuán's book is extant in a re-edition by Gāo Wěngyìng 高替映 (fl. 1702-1703), who combined it with the work of Lín Běnyù (fl. early eighteenth century). According to the aforementioned article for the dating of the editions of Mă's book, Gāo, "Děngyīn," "Shēngwèi” héhuì is older than Méi, Chóngdìng Măshì děngyīn. See also Gěng Zhènshēng 耿振生, Míng-Qīng děngyùn xué tōnglùn 明清等韵学通论 (Běijīng: Yǔwén chūbănshè, 1992), 251.

39. Gāo, "Děngyīn," "Shêngwèi" héhuì, xià:84a (489).

40. Qián Zhàojī 錢肇基, “'Súmí’ sùyuán bǔ” ‘俗謎’溯源補, Gēyáo zhōukān, no. 97 (1925): 5-6; Táo Yùmín 陶燠民, Mǐnyīn yánjiū 閩音研究 (1930; Běijīng: Kējǔ chūbănshè, 1956), 26; Chao, "Fănqiè yǔ bā zhǒng”; Zhāng Tiānbăo 张天堡, “Qièyǔ chūtān” 切语初探, Huáiběi Méishīyuàn xuébào (shèhuì kēxué băn), no. 3 (1986): 131-37; Qǔ Yànbīn 曲彦斌, Zhōngguó mínjiàn mìmì yǔ 中国民间秘密语 (Shànghăi: Shànghăi sānlián shūdiàn, 1990), ch. 2, sec. 1; Fù Zēngxiăng 傅憎享, “Fănqiè yǔ zátán” 反切语杂谈, Xún'gēn, no. 2 (2005): 99-103; Li-yun BauerHsieh, "Aspekte der chinesischen Geheimsprachen," in "Eroberungen aus dem Archiv": Beiträge zu den Kulturen Ostasiens. Festschrift für Lutz Bieg, ed. Birgit Häse and Carsten Storm (Wiesbaden: Harrassowitz, 2009), 84-86.

41. Liú Běncái 刘本才 and Lǐ Chūn 李春, “Shèzì yóuxì jíqí yìngyòng” 射字游戏及其应用, Wénhuà xuékān, no. 3 (2010): 161-62.

42. Gāo, "Děngyīn," "Shēngwèi” héhuì, xià:84a-b. 
they found the matching sounds. ${ }^{43}$ The phonological properties did not all receive the same amount of attention during training. Knowledge of the rhymes was essential for writing and appreciating regularized verse; accordingly, phonologists spent much time on them. Li Rúzhēn 李汝珍 (fl. 1763-1830) stated in his encyclopedic and didactic phonological treatise Lǐshì yīnjiàn 李氏音鑑 (Mr. Lǐ's mirror of phonology; 1805) that in his day, there were “many books that distinguish rhymes, and many practice them”世多分韻之書, 習之者 眾. By contrast, “everybody has difficulties understanding” 人皆難知 that two characters have the same initial, because there were "few books that distinguish initials, and few people practice them” 世罕分母之書, 習之者寡. 44 “For this reason," Lǐ wrote elsewhere as he reiterated the same point, "whenever a student encounters a syllabic spelling pair, he only knows to which rhyme the character belongs, and does not understand under which initial he should arrange it” 故學者每遇切音, 但知字隸某韻, 而不喻應歸何母. ${ }^{45}$ In the case of rhymes, there were "books that one can refer to" 有書可稽; not so with initials. ${ }^{46}$ The difficulty of identifying initials, which provided a raison d'être for Lǔshì yīnjiàn, did not in Lǐ's mind stem from discrepancies between Middle Chinese pronunciation and character readings current in his day. Lî recognized that the Chinese language had undergone sound change since the Middle Chinese (in Lǐ’'s terminology: Táng 唐) period, but argued that it would be foolish to consider Middle Chinese correct and current usage vulgar or incorrect. Rhyme books of past and present were different, and they had to be. ${ }^{47}$ Lǐ was interested in the contemporary language (shíyin 時音) ${ }^{48}$ and its dialects. He taught them with the help of "shooting characters."

Lǐ illustrated the identification of initials in his novel [The Fates of the] Flowers in the Mirror ${ }^{49}$ published in 1827 , when he had a group of characters study a graded rhyme table. ${ }^{50}$ During the course of their voyage to various outlandish places, the characters visit the "land of forked tongues" 歧舌国, where the inhabitants “are not only expert in the laws of human speech sounds, but are also capable of learning the language of birds” 不独精通音律, 并 且能学鸟语. ${ }^{51}$ Once on forked-tongue territory, the travelers take up the study of a rhyme chart acquired from that strange land (see table 3 ). The chart lists rhymes along the horizontal axis and initials on the vertical axis, but the group does not know that. The king of forked tongues was unwilling to share more than the absolute minimum with the strangers, so the chart is unfilled; there are no syllables in the cells of the grid, but only empty circles

43. E.g., Fán Téngfèng 㚞騰鳳, Wǔfāng yuányīn 五方元音, facsimile of the expanded second edition xylograph, cont. Nián Xīyáo 年希堯, in “Sìkù quánshū” cúnmù cóngshū: jīngbù, vol. 219 (1710; Jǐnán: Qí-Lǔ shūshè, 1997), the first edition probably dated from 1654-73, yùnshì:2b-3a; Xú, Yìnfū, 1a-b.

44. Lǐ, Ľ̌shì yīnjiàn, 2:11a-b.

45. Ibid., fánlì: $11 \mathrm{~b}$.

46. Ibid., $3: 21 \mathrm{~b}$

47. Ibid., 1:21a-b.

48. Ibid., 5:30a.

49. Partial translation, unfortunately excluding the phonological passages, in Lǐ Rúzhēn [Li Ru-chen], Flowers in the Mirror, tr. Lin Tai-yi (London: Peter Owen, 1965).

50. Chén Guāngzhèng 陳光政, “Shùpíng Jinghuā yuán zhōng de shēngyùn xué” 述評鏡花緣中的聲韻學, in Shēngyùn lùncóng, ed. Zhōnghuá Mínguó Shēngyùn xué Xuéhuì . . ., vol. 3 (Táiběi: Táiwān xuéshēng shūjú, 1991), 125-48; Wáng Sōngmù 王松木, "Qíshé guó de bù zhuăn zhī mì: Cóng Lǐshì yīnjiàn, Jìnghuā yuán fănsī dāngqián Hànyǔ yīnyùn xué de chuánbō” 歧舌國的不傳之密 : 從《李氏音鑑》、《鏡花緣》反思當前漢語音韻學的傳 播, Hànxué yánjiū 26, no. 1 (2008): 231-60; Paize Keulemans, Sound Rising from the Paper: Nineteenth-Century Martial Arts Fiction and the Chinese Acoustic Imagination (Cambridge, Mass.: Harvard Univ. Asia Center, 2014), 226-28.

51. Lǐ Rúzhēn, Jinghuā yuán 镜花缘, typeset edition, ed. Wú Hào (1827; Nánjīng: Jiāngsū gǔjí chūbănshè, 1996), 90 (ch. 19). 
Table 3. Rhyme tables in Flowers in the Mirror

Simplified representation of the grid acquired by the characters in Lǐ Rúzhēn's novel:

\begin{tabular}{|c|c|c|c|}
\hline zhāng & zhēn & zhōng & zhē \\
\hline$\ldots$ & $\bigcirc$ & $\bigcirc$ & $\bigcirc$ \\
\hline$\ldots$ & $\bigcirc$ & $\bigcirc$ & $\bigcirc$ \\
\hline$\ldots$ & $\bigcirc$ & $\bigcirc$ & $\bigcirc$ \\
\hline$\ldots$ & $\bigcirc$ & $\bigcirc$ & $\bigcirc$ \\
\hline$\ldots$ & $\bigcirc$ & $\bigcirc$ & $\bigcirc$ \\
\hline shāng & $\bigcirc$ & $\bigcirc$ & $\bigcirc$ \\
\hline
\end{tabular}

Lányīn's realization: ${ }^{b}$

\begin{tabular}{|c|c|c|c|}
\hline zhāng & zhēn & zhōng & zhū \\
\hline$\ldots$ & $\bigcirc$ & $\bigcirc$ & $\bigcirc$ \\
\hline$\ldots$ & $\bigcirc$ & $\bigcirc$ & $\bigcirc$ \\
\hline$\ldots$ & $\bigcirc$ & $\bigcirc$ & $\bigcirc$ \\
\hline$\ldots$ & $\bigcirc$ & $\bigcirc$ & $\bigcirc$ \\
\hline$\ldots$ & $\bigcirc$ & $\bigcirc$ & $\bigcirc$ \\
\hline shāng & shēn & {$[$ shō]ng } & shū \\
\hline
\end{tabular}

Lányin realizes that the syllables on the sixth line have the same relationship among them as those on the first line do; the circles on the sixth row obtain one phonological property (the initial) from the vertical axis, and another (the rhyme) from the horizontal axis.

b. Based on Ľ̀, Jinghuā yuán, 149-50 (ch. 19).

(O). Seeking a way to understand the chart, the travelers, including the characters Wănrú and Lányinn, decide to heed the proverbial advice to "read a book a thousand times / and the meaning will appear" 书读千遍, 其义自见 (unambiguously an argument for rote learning):

Wănrú also twice read through zhāng, zhēn, zhōng, zhü [on the grid's horizontal axis]. Holding the sheet of character genera, she looked them over a number of times with Lányīn. Suddenly, Lányīn said: "Adoptive father, look at the character shāng on the sixth row [of the vertical axis]. What if we would read it in the manner of zhāng, zhèn, zhōng, zhü? Is it not shāng, shēn, [shō] $n g, s h \bar{u}$ ?"

婉如也把“张”、“真”、“中”、“珠”读了两遍, 拿着那张字母, 同兰音看了多时。兰音猛 然说道: “寄父, 请看上面第六行“商”字, 若照“张”、“真”、‘中”、珠”一例读去, 岂非商” 、“申’、“桩”、“书”么?”52

The technique that Lányīn had identified was similar to the recitation of series of alliterative "auxiliary syllable initial specifiers" (zhùniǔ zì 助紐字), in use at least since the twelfth century within rhyme table studies, ${ }^{53}$ but clearly unfamiliar to the characters in the novel. Lǐ presented Lányīn as having mastered the principles of fănqiè spelling by osmosis, thereby enabling the group to fill out the cells of the grid. Following Lányin's epiphany, the group proceeded to use handclaps to shoot some characters, here under the name of "transmitting sound like echoes in an empty valley" 空谷傳聲, 54 a phrase from a primer known to all literates (Qiān zì wén 千字文 [The thousand character essay]) ${ }^{55}$ and the common name for

52. Ibid., 151 (ch. 31).

53. Coblin, "Zhāng Línzhī on the Yùnjìng," 127-28.

54. Ľ̀, Jinghuā yuán, 153 (ch. 31).

55. Lǐ Yìān 李逸安, ed. and tr., “Sān zì jīng,” “Băi jiā xìng,” “Qiān zì wén,” “Dìž̀ guī”三字经·百家姓·千 字文·弟子规 (Běijīng: Zhōnghuá shūjú, 2010), 109. 
"shooting characters" used by Hú Yín, cited above. Lǐ Rúzhēn, furthermore, recommended the use of the game for learning basic phonological principles in his aforementioned compendium. The practice was evidently widespread; it was thanks to "the game of shooting characters” (shèzì zhī xì 射字之戲) that Láo Nǎixuān 勞乃宣 (1843-1921) got hooked on phonology as a child. ${ }^{56}$

The pedagogical practice of memorizing the sequences that formed graded rhyme tables explains why the game of "shooting characters" was re-appropriated as a phonological teaching tool. Introductions to phonological learning often used this name, or "shooting for the mark" (biāoshè 標射) ${ }^{57}$ — terms that, unlike "striking the drum," were entirely figurative—-to describe the use of the grid to learn fănqiè spellings.

\section{GRADED RHYME TABLES AND HAND DIAGRAMS}

Figurative or extended usage of terms from the game in books on rhyme table phonology indicates that the practical, non-written character of "shooting characters" appealed to writers who wanted to make phonology easier to learn. Pedagogues used the tables, either as represented on the learner's hands, or as printed grids in reference works, to replace some of the analytical operations of phonology with movements of thumb and fingers.

Already some of the earliest extant graded rhyme tables, including Yùnjìng, were used to obtain readings from fănqiè spellings by matching characters according to their placement in grids and columns. By the early seventeenth century at the latest, this practice had become associated with the game of "shooting characters." The very influential rhyme chart ascribed to one Lí Shìzé 李世澤 (n.d.), which relied on a technique similar to the one described by Zhāng Línzhī in the twelfth century, made the association between the tables and the game. Indeed, Lǐ's table might originally have been titled "Biāoshè qièyùn fă" 標射切韻法 (Rhymes spelled by shooting targets) or “Qièyùn shèbiāo" 切韻射標 (Shooting targets and spelling rhymes) ${ }^{58}$ It circulated most widely, however, as the second of two graded rhyme tables appended to Méi Yīngzuò's 梅膺祚 (fl. 1615) influential graphological dictionary Zìhuì 字彙 (The characters collected; 1615), where it carries the title "Yùnfă héngtú" 韻法 横圖 (Horizontal chart for the phonological method). Perhaps Méi changed the title to match it to "Yùnfă zhítú" 韻法直圖 (Vertical chart for the phonological method), which preceded it in the dictionary's appendix.

Books influenced by the “horizontal chart” include Jiă Cúnrén’s 賈存仁 (fl. 1775) phonological primer. Jiă instructed the student to rely on the "shooting-the-target spelling method" (biāoshè qièfă 標射切法) to decode fănqiè spellings using the tables. He explained that the method “is similar to hitting a target with an arrow” 如射之中標也. The actual shooting referred to the final operation of pairing a rhyme with an initial, each of which was represented on one of the table's axes. If I understand Jiă's and other similar texts correctly, the method advocated involved drawing the finger along the columns and rows of the table to find the cell containing the desired character. ${ }^{59}$ Lǐ Shìzé's table called it "pointing and shooting [toward the targets]" (zȟ̌ ěr shè yān 指而射焉). ${ }^{60}$

56. Láo Nǎixuān, Děngyùn yīdé 等韻一得, 2 vols., xylograph (Wúqiáo Guānxiè, 1898), vol. 1, xù:1b.

57. Yáng Zhìtǐ 楊志體, Yīnyùn huàyī 音韻畫一, cont. Guō Yùdé 郭裕德, xylograph (Wèicài Táng, 18841886), held at Taiwan Normal Univ. Library (call number A 940 633), 25a-b.

58. Lǐ Shìzé, "Qièyùn shèbiāo," chap. 32 in Shuôfú xù, in Xùxiū "Sìkù quánshū": ž̌bù, vol. 1191, facsimile of xylograph; Lǐ Jūn 李军, “Qièzì jiéyào” yánjīu 《切字捷要》研究 (Běijīng: Zhōnghuá shūjú, 2015), 17.

59. Jiă Cúnrén 賈存仁, “Děngyùn jīngyào” 等韻精要, in Hănjiàn yùnshū cóngbiān, vol. 2, facsimile of xylograph (1775), túshuō:22a-b.

60. Méi Yīngzuò 梅鷹祚, Zìhuì 字彙, xylograph (Méi Shìqiàn, Méi Shìjié, 1615), appendix (juànmò 卷末), yùnfă héngtú:16b. Wú Lăng, Wǔ shēng fănqiè zhèng[yùn] 五聲反切正均, facsimile of xylograph, in Cóngshū jíchéng 
The method that Ľr, Jiă, and other rhyme-table authors described was similar to the game of shooting characters in that it consisted in identifying phonological properties in series of syllables (the axes of initials, finals, etc.). However, the element of memorization, essential in the original game, had here been made obsolete by the use of printed tables. The student did not necessarily have to count, but rather move his fingers along the rows and columns of the graded rhyme tables to find corresponding locations. In Jiă's book and Lǐ Shìzé's graded rhyme table, "shooting characters" was primarily a metaphor for the manipulation of twodimensional grids.

A learner could, however, proceed to playing the game after having learned the method from grids, rather than through memorizing jingles or other sequences of syllables. Wú Lăng 吳烺 (fl. 1751) ${ }^{61}$ remarked that "the method of shooting characters requires that two individuals either be versed in fănqiè, in sounds in columns [of the graded rhyme tables], or that they have someone show them using versified text”射字之法, 須兩人熟於反切、縱音, 或有人示以詩詞文字. Wú was of the opinion that the use of graded rhyme tables was a “much easier method" 尤為簡易法 than fănqiè. ${ }^{62}$

The terminology of "shooting characters" also entered a different product of rhyme table studies: the phonological hand diagram. A kind of kinesthetic mnemonics, such diagrams used other techniques than the two-dimensional table to relieve the practitioner's memory and reduce the reliance on a printed text. Hand diagrams were-and here I am borrowing a description originating in an entirely different context- "cognitive schema for organising, remembering and manipulating ... information." As with other such schemata, nothing had to be written for a Chinese phonological hand diagram to be used; practitioners would have the names for the diagram's positions "in their heads." 63

Originating outside phonology, the initially Buddhist hand mnemonics of "circular or square diagram[s] transferred onto the palm side of the fingers" 64 were notably used in divination and medicine. Their use in phonology is attested since at least the thirteenth century. ${ }^{65}$ A link existed between hand diagrams and charts or tables (tú), of which the graded rhyme tables were one example, in that both relied on two dimensions. Yet the appearance of phonological hand diagrams also reflected the study of speech sound's strong association to numerical cosmologies, which were also at the basis of divination practices. ${ }^{66} \mathrm{It}$ is suggestive that Zhào Yǔshí's description of the "shooting characters" game (the earliest one that we have) juxtaposed it precisely with divinatory practices.

xùbiān, vol. 75, undated, but printed in the mid to late eighteenth century, wǔ shêng fănqiè zhèngjūn[=yùn]:33a, quoted these words as Méi Yīngzuò's.

61. Tu Lien-chê, "Wu, Ching-tzŭ," in Hummel, Eminent Chinese, 2:867.

62. Wú, Wǔ shēng fănqiè zhèng[yùn], wǔ shēng fănqiè zhèngjūn[=yùn]:36a-b.

63. Charles O. Frake, "Cognitive Maps of Time and Tide Among Medieval Seafarers," Man 20, no. 2 (1985): 264, where these statements unsurprisingly do not refer to Chinese phonological hand diagrams. I owe the realization that the study of cognition (as pursued in the history of navigation) is relevant to the phonological hand diagrams to Stéphanie Homola, "Hand Mnemonics and Counting Skills: Reducing Uncertainty through Fate Computation" (paper presented at the "Accounting for Uncertainty" inaugural workshop, Max Planck Institute for the History of Science, Berlin, June 1, 2016).

64. Marta E. Hanson, "Hand Mnemonics in Classical Chinese Medicine: Texts, Earliest Images, and Arts of Memory," Asia Major 21.1 (2008): 334.

65. E.g., Sòngběn Qièyùn zhǐzhăng tú, 11b (22).

66. Hirata Shōji 平田昌司, “Huángjí jīngshì shēngyīn chānghé tú yǔ Qièyùn zhǔzhăng tú: Shì lùn yǔyán shénmì sīxiăng duì Sòng dài děngyùn xué de yǐngxiăng”『皇極經世唱和圖』與『切韻指掌圖』: 試論語言神秘思想 對宋代等韻學的影響, Tōhō gakuhō 56 (1984): 179-215. 
The hand diagrams and the mnemonics they represented were particularly useful for recalling lists, items in a specific order, that could be accessed both backwards and forwards. ${ }^{67}$ In phonology, they served to facilitate learning the sequences of initials and rhymes and then using them to produce spellings.

The origin of one tradition of phonological hand mnemonics was the anonymous chart "Yùnfă zhítú," already mentioned, which Méi Yīngzuò acquired in 1612 and published three years later. The chart's author was Sūn Zhēn 孫貞 (n.d.), who had originally titled it "Jīng wěi tú” 經緯圖 (Warp and weft chart) and published it in his Qièzì jiéyào 切字捷要 (Quick summaries of character spelling; probably dating from 1576-80). ${ }^{68}$ The simplification of the sound system carried out in Sūn's chart according to current Northern literary pronunciation, which was also reflected in Méi's reworking of it, made it appealing to many phonologists. In Méi's version, the "vertical" element of the chart lay in its listing of the initials on the vertical axis, so that syllables with the same initial appeared in the same row. Each table contained one out of forty-four rhyme groups and listed the four Middle Chinese tones on the horizontal axis. ${ }^{69}$

Méi's "vertical" chart operated with a set of thirty-two initials. This was a number that could be made to fit on the human hand (see figure 2): "Each finger contains four positions [viz. the finger tips and the the three joints], so four fingers together contain sixteen positions; double that [by creating two columns on each finger], and you get thirty-two, which accommodates the thirty-two initials” 每指四位, 四指共十六位; 重之, 則三十有二, 而三十二音備矣. The practitioner was instructed, when looking for a syllable, to imagine the series of thirty-two syllables within the relevant rhyme projected onto the hand, thereby recalling their order more easily. ${ }^{70}$

The method of fănqiè spelling in "Yùnfă zhítú" had one important similarity with the game of "shooting characters": it involved the commutation of phonological properties to numbers. As we saw, Lř Rúzhēn, in a later work, noted, through the words of an imaginary interlocutor, that "everybody" had difficulties identifying syllables with the same initial, whereas an understanding of the functioning of rhymes was much more widespread. Probably reflecting this situation, "Yùnfă zhítú" assumed that the reader could easily identify a syllable's rhyme. It was the difficult identification of the initial that the commutation to numbers sought to facilitate.

According to the instructions that accompanied the chart, the reader should, when faced with a pair of fănqiè spellers, first go to the rhyme to which the first fănqiè speller belonged, find the speller within that rhyme, and note its position. "The first speller determines the position," the instructions read, "according to which the second speller obtains the pronunciation” 上字定位,下字照位取音. ${ }^{71}$ Sūn's original chart already functioned in this way. ${ }^{72}$

If we assume, as did Sūn and Méi, that a reader upon encountering a syllable would be able to identify to which rhyme it belonged-perhaps by "reading through [the rhymes] quickly aloud” 順口讀去, ${ }^{73}$ as the instructions accompanying the "vertical chart" described it - the reader would then go to the appropriate rhyme and read through the syllables it contained until he hit upon one that was homophonous with the first speller of the fănqiè pair. If

67. Stéphanie Homola, "Les usages de la main dans les calculs divinatoires," Études chinoises 33.1 (2014): 126.

68. Ľ̌, “Qièzì jiéyào” yánjiū, 21-22.

69. Lǐ Xīnkuí 李新鬼, Hànyǔ děngyùn xué 汉语等韵学 (Běijīng: Zhōnghuá shūjú, 1983), 249-50.

70. Méi, Zihuì, appendix, yùnfă zhítú:39b.

71. Ibid., appendix, yùnfă zhítú:1b.

72. Lǐ, "Qièzì jiéyào" yánjiū, 30-31.

73. Méi, Zìhù̀, appendix, yùnfă zhítú:39b. A similar description is found in Fānqiè zhǔzhăng, 1522. 


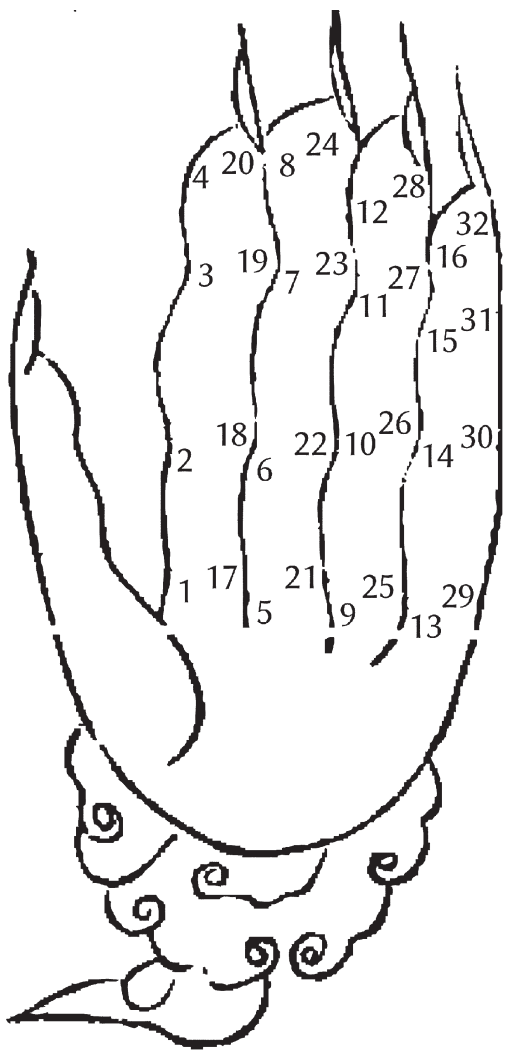

The numbers on the fingers represent syllable initials. ${ }^{c}$

c. Representation of Méi, Zìhù, appendix, yùnfă zhítú:39b (not to scale).

FIG. 2. The phonological hand diagram in "Yùnfă zhítú"

the syllables were homophonous, they eo ipso shared the same initial, and these tables were structured so that syllables with the same initial occurred in the same position in each of the rhymes. The reader would therefore remember the position of the syllable (homophonous with the first speller) within its rhyme, go to the rhyme to which the second fănqiè speller belonged, and find the syllable that occupied the corresponding position in that rhyme. This second syllable, which by being in the rhyme of second fănqiè speller shared its final and tone, was the syllable spelled by the fănqiè pair, as it, thanks to its position within the rhyme, had the same initial as the first speller.

The reader never had to isolate the initial of any of the syllables involved. All he had to do was to find a homophone in one rhyme, note its position in the series, and retrieve a syllable from the same position in the series of a different rhyme. The reader could, as in Lǐ Shìzé's "horizontal" chart or in Jiă Cúnrén's primer, perform this operation using the printed tables. He could also, however, use the hand diagram, successively imagining the rhymes of the first and second spellers projected onto his hand.

The "vertical" chart influenced several works in the Qing period. One of them was the primer Qièyīn jiéjué 切音捷訣 (Quick mnemonics for phonological spelling) from 1880 by 
the scholar Lì Héng 麗珐 (c. 1841-1888) from Zhūjì 諸暨. ${ }^{74}$ Lì followed "Yùnfă zhítú" closely, and included both the hand diagram and some of the explanations from the original chart in his book. ${ }^{75}$ Lì changed the number of both rhymes and initials to thirty-six, ${ }^{76}$ but relegated ten of them to be read separately at the end of the tables. ${ }^{77}$

Lì's book inspired another work that allows us to see in more detail how hand diagrams related to the character-shooting method: the phonological primer Qièyin méngy̌n 切音蒙引 (Syllabic spelling primer; 1883), by the seasoned teacher Chén Jǐn 陳錦 (literary name Bǔqín 補勤; fl. 1821-1884). Chén was from Shāoxìng 紹興, a town in relative proximity to Lì’s native Zhūjì. In addition to Lì, Chén was influenced by another contemporary, Wāng Liú 汪瑬 (n.d.) from Ānhuī. The book from which Chén appears to have learned of Wāng's ideas appeared in 1881 under the title Kōnggǔ chuánshēng, but, according to Lǐ Xīnkuí 李新鬼 (1935-1997), Wāng had written it several decades earlier. Wāng's book, in turn, was based on a work by Wú Lăng and one Jiāng Yúnqiáo 江雲樵 (n.d.) known as Jīnlíng chuánshēng pǔ 金陵傳聲 譜 (The Jīnlíng [Nánjīng] sound-transmitting chart). According to Lǐ Xīnkuí, Wāng’s book was used to play the game of shooting characters and represented current prestigious reading pronunciation, ${ }^{78}$ which it presumably sought to impart. Under Wāng's influence, Chén's book strengthened the association between hand mnemonics and "shooting characters."

As an introduction to the study of phonology, Chén's book served to familiarize students with key phonological categories. It suited the pedagogical purposes of his book to explain the areas where students were most likely to run into difficulties, while keeping the overall presentation as simple as possible. The pronunciation indicated by Chén's fănqiè spellings is close to the dialect currently spoken in Chén's hometown of Shāoxìng. ${ }^{79}$ It appears that Chén, to the greatest extent possible, tried to provide fănqiè spellings that when read aloud accorded with how the characters in question were read in Shāoxìng, while remaining valid also when treated as spellings for Middle Chinese.

Chén's book used fifty-four finals, ${ }^{80}$ of which eighteen were entering-tone finals. The latter included, the book contained 125 rhymes defined as final plus tone. Chén was well aware that his division of rhymes did not match up exactly to the "official rhymes" (guānyùn 官韻) prescribed in official examination poetry. However, Chén believed that "the reader will be able to guess" which rhymes corresponded, adding that he hoped the reader would not "bring up the contradictions” 讀者意會得之; 幸勿議其枘鋓. 81

All of the twelve examples that Chén gave to illustrate the functioning of the hand diagram worked when read in Shāoxìng dialect. The student never had to accept pronunciations as nominally correct even though they did not correspond to usage in his own dialect. When Middle and Shāoxìng Chinese did not entirely correspond, Chén preferred accuracy in the student's vernacular over accuracy in Middle Chinese. In the instructions to the hand dia-

74. Studied in Chén Dānlíng 陳丹玲, “Qièyīn jiějué yīnxì yánjiū” 《切音捷訣》音系研究 (master’s thesis, Táiwān Shīfàn Dàxué, 2009).

75. Lì Héng, Qièyīn jiéjué, xylograph (Zhūjì: Zhígǔ Táng, 1880), held at Sun Yat-sen Library, Guăngzhōu (call number 09345), 2a-3a.

76. Gěng, Míng-Qīng děngyùn xué tōnglùn, 235.

77. [Chén J̌̌n 陳錦] (Bǔqín 補勤), Qièyīn méngy̌n 切音蒙引, xylograph (1883), held at Taiwan Normal Univ. Library (call number A 940 505), 10a.

78. Ľ̀, Hànyǔ děngyùn xué, 301-4.

79. Inferred from Sū Zhǐyí 蘇芷儀, “Qièyīn méngyǐn yīnxì yánjiū” 《切音蒙引 》音系研究 (master's thesis, Zhōngguó Wénhuà Dàxué, 2012). For Shāoxìng dialect, I follow Wáng Fútáng 王福堂, "Shāoxìng fāngyán tóngyīn zìhuì” 绍兴方言同音字汇, Fāngyán, no. 1 (2008): 1-17.

80. Following the definition in William H. Baxter, A Handbook of Old Chinese Phonology (Berlin: Mouton de Gruyter, 1992), 6-7.

81. [Chén], Qièyīn méngy̌n, 12a. 
gram, departures from Middle Chinese concerned only the rhyme (tables 4 and 5, both minor departures), confirming that Chén's focus was indeed on the initials.

In some places in the tables, however, Chén was compelled to depart from spellings seen in EMC sources in order to maintain accuracy in Shāoxìng dialect also in the case of the initials, as seen in table 6. Yet even LMC sources like Qièyùn zhǔzhăng tú (see n. 20), ${ }^{82}$ almost seven hundred years old by Chén's time, made adjustments to these kinds of spellings, which no longer accorded with the pronunciation of its time. Furthermore, Chén's new fănqiè would probably have yielded a correct pronunciation even in EMC, so it was a minor departure indeed.

Chén's tables listed the traditional thirty-six initials on one of its axes, but in the hand diagram, only twenty-four initials were used, corresponding to twenty-three pronunciations. ${ }^{83}$ Chén excluded the remaining eight Middle Chinese initials, which were not distinguishable in Shāoxìng Chinese, from his hand diagram (table 7).

Chén's book simplified the phonological framework so as not to make irreconcilable differences apparent between Middle Chinese and the variety of Shāoxing dialect that he and his students used. The purpose of the simplification was pedagogical, and the key phonological tool was the hand diagram.

Chén's “target-and-arrow hand diagram” (biāo jiàn zhăngtú 標箭掌圖) taught students to decode fănqiè spellings. Chén, a teacher, knew that fănqiè appeared abstract to his students. Chén used a terminology derived from the character-shooting game to describe how the diagram —and, by extension, fănqiè — worked. Chén had learned phonology (qièyīn 切 音) as a child and then taught it for half a century. He explained that "senior scholars, in all the discussions I listened to, always brought up "transmitting sound like echoes in an empty valley' (Kōnggǔ chuánshēng) as their secret teaching [method]” 每聞老生常談, 軴舉空谷 傳聲為秘教. ${ }^{84}$ Chén's source for this teaching method was Wāng's eponymous book, whose structure (tǐlì 體例) Chén thought similar to that in Lì’s primer, by which he was also much inspired. Chén wrote that Lì "made the reader count [my emphasis] horizontally to obtain the initial within the rhyme, and count vertically to obtain the rhyme within the initial" 令 讀者橫數而得韻中之音, 直數而得音中之韻. ${ }^{85}$ This congruence inspired Chén to base his book on Lì's primer, on "the methods of tapping on the seat and recording numbers [used in] Transmitting sound like echoes in an empty valley” 《空谷傳聲》撲席記碼法, as well as on character-shooting hand diagrams that he had consulted. ${ }^{86}$ These influences explain the terminology that Chén used to explicate his diagram.

Chén called the initial the target (biāo 標), the rhyme the arrow (jiàn 箭), and the spelled syllable the mark, or bull's-eye ( $d i \grave{~}$ 的). ${ }^{87}$ After having chosen the target, the student would

82. Sòngběn Qièyùn zhǔzhăng tú, 10a-b (19-20).

83. Chén stated that the sound of two of the twenty-four initials, $\gamma$ 喻 (yù) and $x \gamma$ 㕅 (xiá), were similar in pronunciation, yet he kept both to maintain the symmetry of the system (four laryngeals [hóuyīn 喉音] corresponding to four each of velars [yáyīn 牙音], labials [chúnyīn 脣音], dental sibilants [chǔtóu yīn 齒頭音], and so on). Sū Zhǐyí concluded that proper reading pronunciation in Chén's understanding included only one sound $h$ where Middle Chinese sources indicated either $\gamma$ or $x y$ : Sū, "Qièyīn méngy̌n yīnxì yánjiū," 124.

84. [Chén], Qièyīn méngy̌n, 4b.

85. Ibid., 5a.

86. Ibid., 6a.

87. The distinction between the target and the mark/bull's-eye is not entirely clear from the point of view of the metaphor itself, nor from consideration of the reality represented; indeed, another account called the initial by the two-syllable name biāodì (Fānqiè zhǐzhăng, 1520). These terms are also discussed in reference to fănqiè (but not graded rhyme tables) in Yuen-ren Chao, "The Problem of the Chinese Language," in Linguistic Essays by Yuenren Chao, ed. Zong-ji Wu and Xin-na Zhao (1916; Běijīng: Shāngwù yìnshūguăn, 2006), 20. It is unclear if Chao was aware of the use of these terms in the context of the game. 


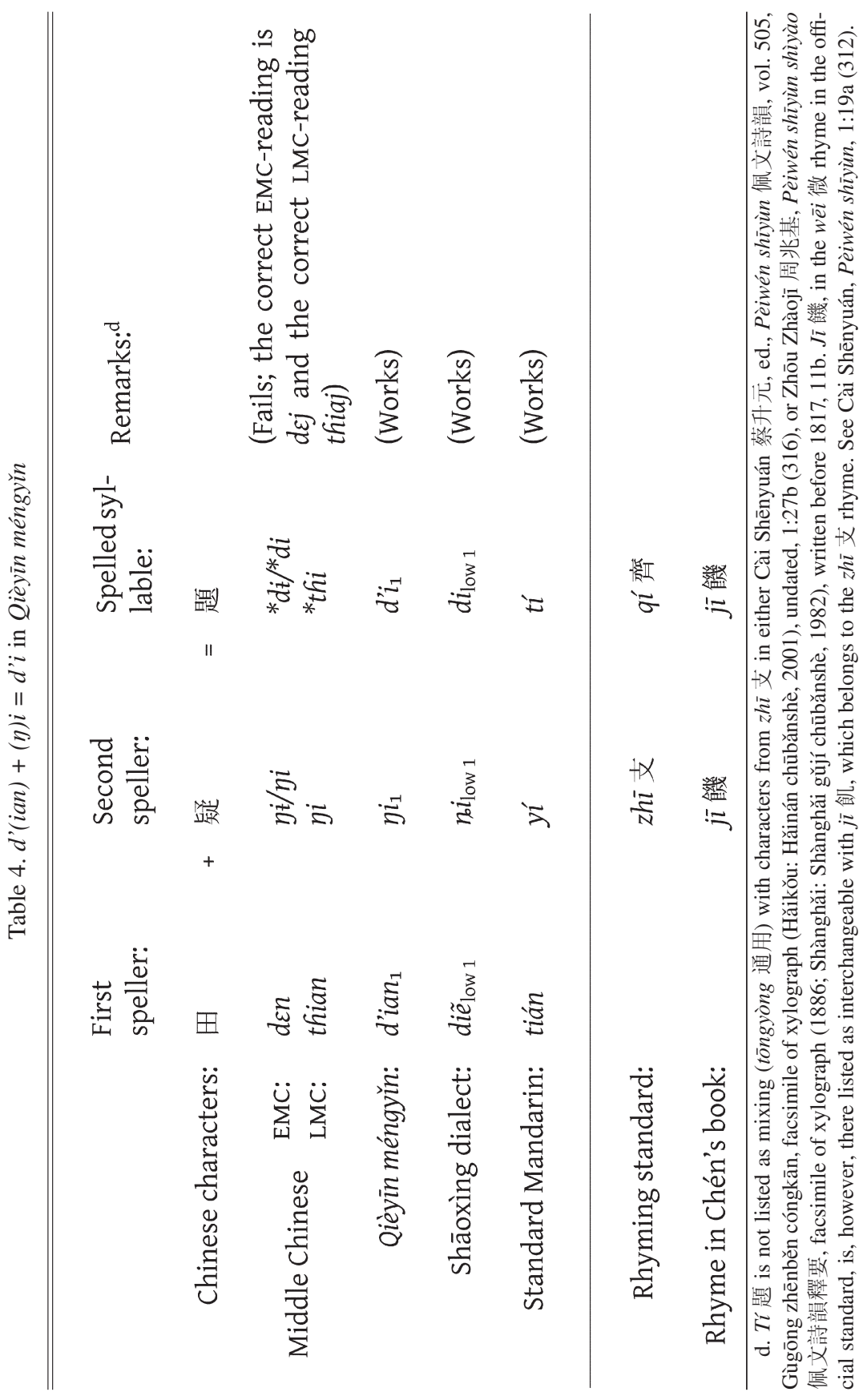




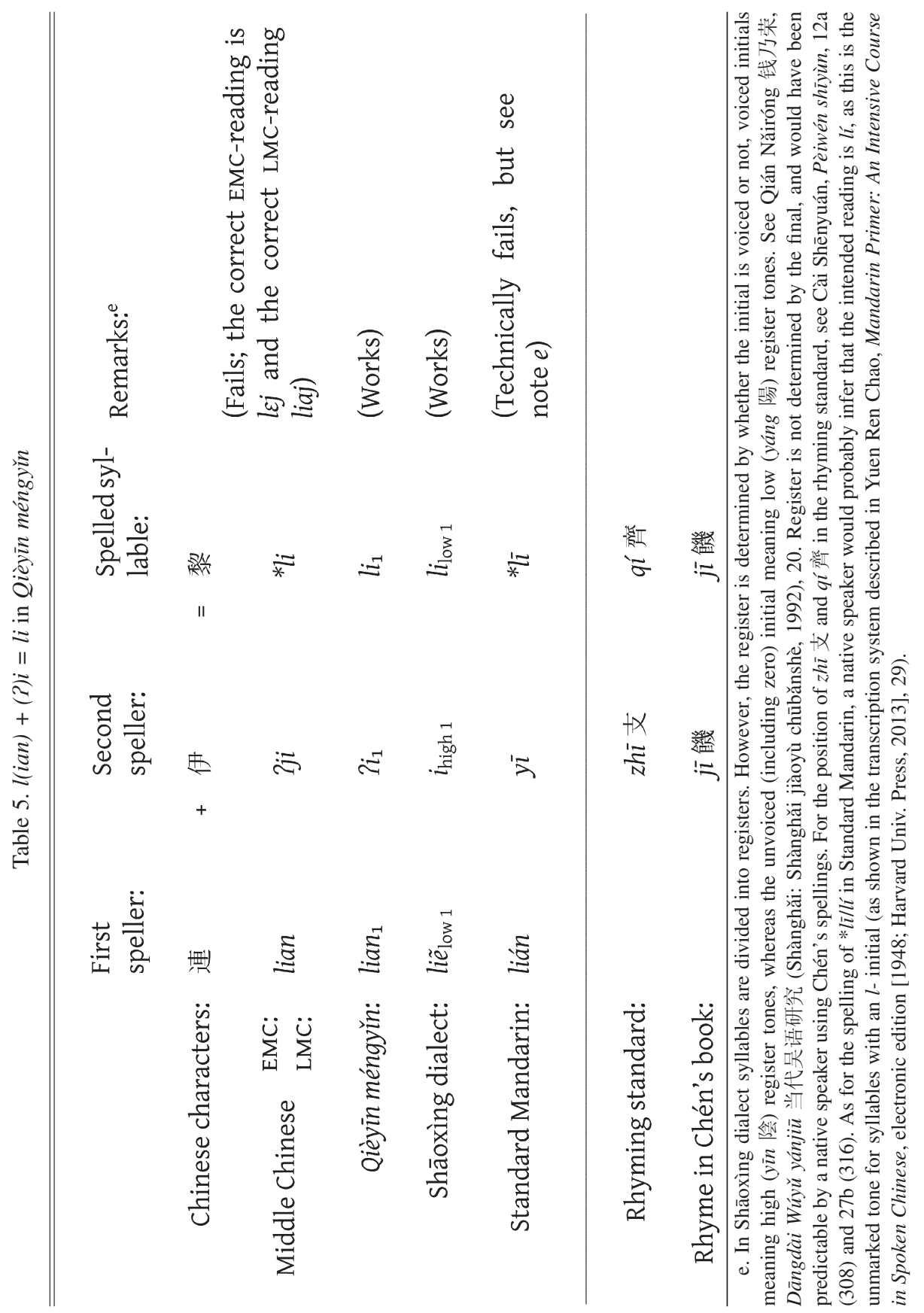


Table 6. $p(u)+\left(d^{\prime}\right) \partial \eta=p a \eta$ in Qièyīn méngy̌̀n

\begin{tabular}{|c|c|c|c|c|c|}
\hline \multicolumn{6}{|c|}{ Old spelling:f } \\
\hline \multirow[b]{5}{*}{ Qièyīn méngyìn } & characters: & 方 & + 鄧 & $=$ 堋 & \\
\hline & EMC: & puay & $d \partial \eta^{\mathrm{h}}$ & $\mathrm{N} / \mathrm{A}$ & (Initial is bilabial) \\
\hline & ial in EMC: & $p$ - 幫 & & & \\
\hline & LMC: & fjyay/fay & thวăp' & $\mathrm{N} / \mathrm{A}$ & $\begin{array}{l}\text { (Would fail, as the initial is } \\
\text { labiodental) }\end{array}$ \\
\hline & $\begin{array}{l}\text { Reading: } \\
\text { Initial: }\end{array}$ & $\begin{array}{l}\text { fyan }_{1} \\
f \text { - 敷 }\end{array}$ & $d^{\prime} \partial \eta_{3}$ & $\begin{array}{l}*{ }^{*} \partial \eta_{3} \\
p-\text { 幫 }\end{array}$ & $\begin{array}{l}\text { (Fails; the correct } \\
\text { reading is bilabial) }\end{array}$ \\
\hline \multicolumn{2}{|c|}{ Shāoxìng dialect: } & $f b \eta_{\text {high } 1}$ & day $\eta_{\text {low } 3}$ & ${ }^{*} f \partial \eta_{1}$ & $\begin{array}{l}\text { (Fails; spelled syllable } \\
\text { does not exist) }\end{array}$ \\
\hline \multicolumn{2}{|c|}{ Standard Mandarin: } & fāng & dèng & *féng & $\begin{array}{l}\text { (Fails; the correct } \\
\text { reading is bèng [al- } \\
\text { ternative form of } \\
\text { 塴]) }\end{array}$ \\
\hline
\end{tabular}

Chén's new spelling:

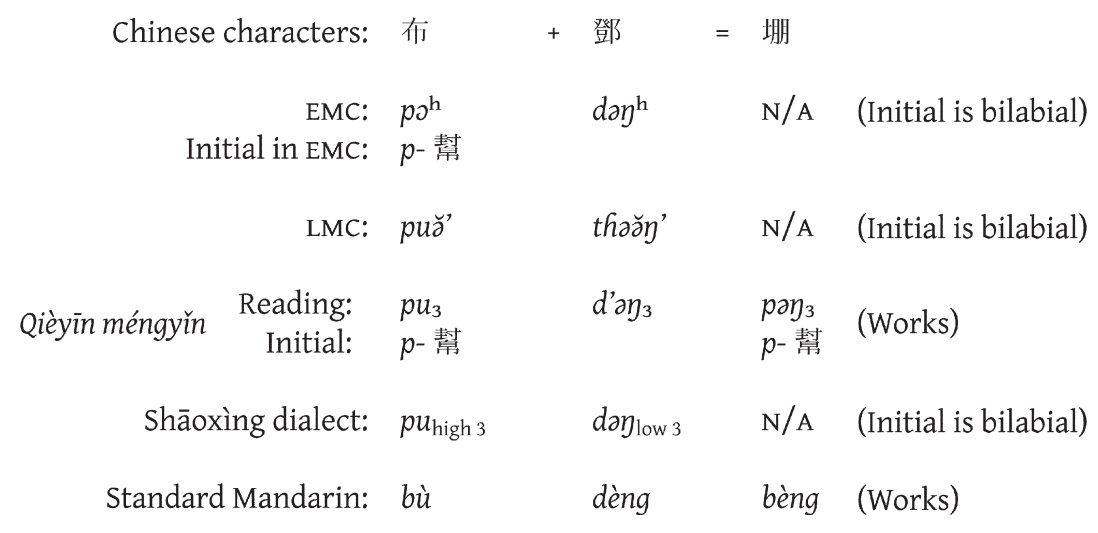

f. For the old spelling see Yú, Xīn jiào hùzhù Sòng-běn "Guăngyùn”, 4:48b (434). It is discussed in [Chén Jǐn], Qièyīn méngy̌̌n, 9b; Sū Zhǐyí, "Qièyīn méngy̌nn yīnxì yánjiū," 97. EMC characters that are listed as N/A are not listed in Pulleyblank, Lexicon of Reconstructed Pronunciation in Early Middle Chinese, Late Middle Chinese, and Early Mandarin. The character fāng 方 is not listed in [Chén], Qièyīn méngy̌̌n, but the pronunciation is inferred on the basis of the spelling of fäng 芳 on 32a.

find the right arrow, shoot, and hit the mark. ${ }^{88}$ "'The concepts of 'target', 'arrow', and 'mark' are the main ideas of this book" 標箭的名義, 為是書主腦, Chén asserted. ${ }^{89}$ Following his predecessors, Chén instructed the reader to project a grid onto the palms of his hands. Fluent

88. [Chén], Qièyīn méngy̌̌n, 15a.

89. Ibid., 12a. 
Table 7. Initials excluded from Qièyīn méngy̌̌n hand diagram

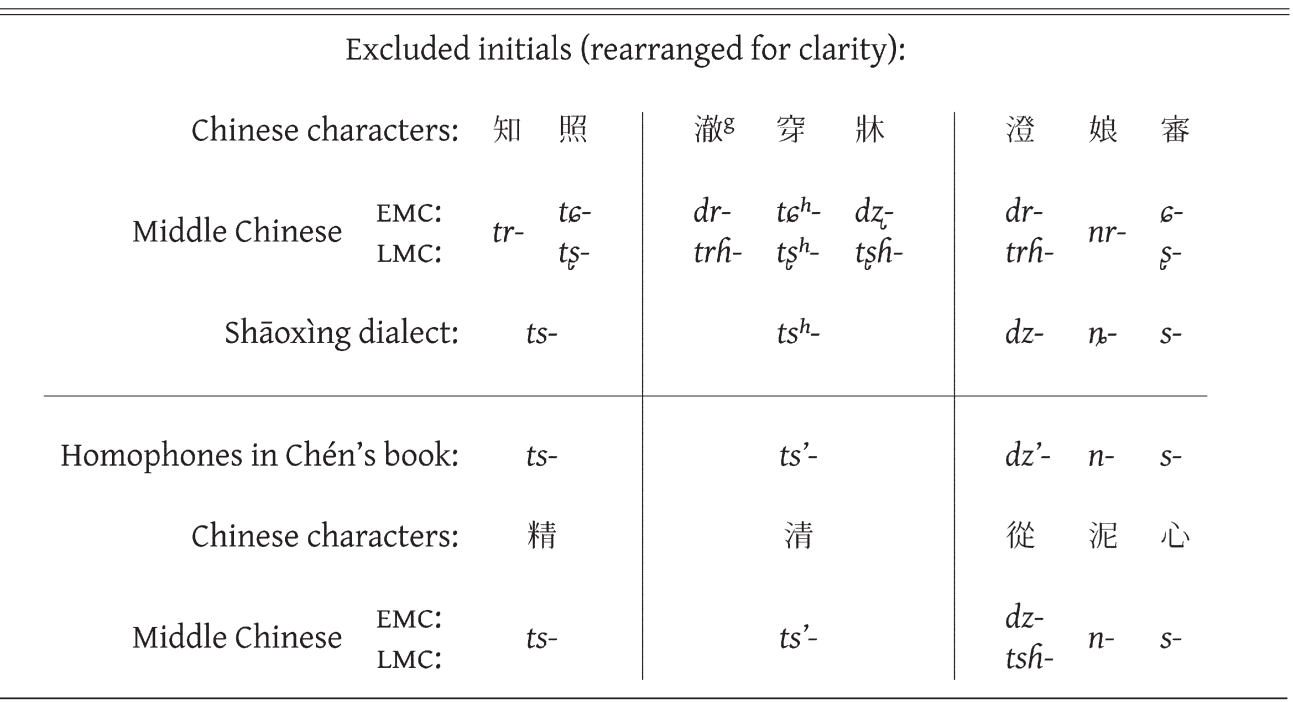

g. Viz., 徹.

usage of the hand diagram throughout all of the rhymes demanded that the reader imagine characters written on the palms, which varied with the rhyme, but while learning, one might conceivably write out one rhyme there (Chén did not specify).

Chén's diagram required the use of both hands. As mentioned, his hand diagram operated with a reduced set of twenty-four initials, which, being smaller than the repertoire in "Yùnfă zhítu," easily fit onto only one hand. He needed both hands, however, to let the practitioner count within two rhymes simultaneously in order to decipher a fănqiè spelling pair. "The method," Chén specified, "proceeds by counting through the rhyme to which the target [sc. the first fănqiè speller] belongs using the right hand's thumb” 法以右手大指, 數標韻母. ${ }^{90}$ The reader should, on the right hand, count from the right: "Once you know the position of the target, press down and do not move" 至標為第幾位, 按定勿動. The reader should now turn his attention to the left hand: "Then count through the rhyme to which the arrow [sc. the second fănqiè speller] belongs using the left hand's thumb; when you reach the position marked by the right hand's thumb, you have found the mark [sc. the spelled syllable]" 再以 左手大指, 數箭韻母; 至右指所按部位, 即其的. ${ }^{91}$ This process is illustrated in figures 3 and 4.

One of the anonymous reviewers of this paper remarked, in reference to Chén's hand diagram, that a reader will wonder why so many complicated maneuvers were needed when one need only put the fănqiè together to arrive at the correct result of the spelling operation. I agree that we today find Chén's method roundabout, preferring instead the linear, alphabetic formula $h\left(u_{1}\right)+\left(d z^{\prime}\right) u o \eta_{1}$ to understand the spelling of $h u o \eta_{1}$ illustrated in figure 4 . I further agree that some Chinese scholars, especially by the late nineteenth century, understood fănqiè in this way. Yet even if Chén thought about fănqiè as the manipulation of linearly

90. Chén did not use the word yùnmǔ in the sense of final, which is the meaning that the term has in technical usage today.

91. Ibid., 15a. 
arranged subsyllabic sounds-I have found no evidence that he did-he decidedly did not, after several decades of pedagogical experience, think that it was the best way to teach the method to students.

The avoidance of Middle Chinese spellings that did not yield correct readings in Shāoxìng Chinese, and the reliance on the local vernacular generally, were reasonable in a book for beginners. It precluded difficulties that would have distracted from Qièyin méngy̌n's main purpose: the teaching of the fănqiè operation, with a focus on the notoriously difficult identification of initials. In the hand diagram, the centerpiece of Chén's pedagogy, it was precisely the initial (of the second speller) that was commuted to a number, which enabled the reader to find the initial of the first speller, and thereby also of the spelled syllable, without analyzing its pronunciation.

The history of cognition has shown that different conceptualizations of the same operation - in this case, fănqiè — are historically contingent, differing over time or between individuals with different educational background. ${ }^{92}$ Even though some late imperial Chinese scholars probably thought of fănqiè as a linear, alphabetic process, students who, having never learned to use an alphabet, needed phonology only as a tool to find appropriate readings for unknown characters encountered in dictionaries or other books might have found the mechanics of the hand diagram much more intuitive and appealing.

Chén's own explanations show how he thought that the fănqiè process, with its main difficulty of identifying initials, was most easily taught. Nothing in the explanations leads me to think that he thought of teaching it as the linear, alphabetic formula we use to explain it today. Rather, Chén made use of numbers and the first calculator known to humans: the hand. ${ }^{93}$

By means of the spellings in table 8, Chén wanted to show that only the initial of the first speller determined the pronunciation of the spelled syllable. The first of the two fănqiè pairs seen there spelled different syllables. Chén called this phenomenon "identical arrows [second spellers] and different targets [first spellers] yielding different marks [spelled syllables]" 同 箭異標故的異. This phenomenon contrasted with one called “different arrows and identical targets yielding identical marks" 異箭同標故的同, illustrated through the second spelling pair in table 8. In these pairs, the spelled syllables were identical, even though the characters used to spell them were not. Chén explained how to ascertain that these spellings yielded the same result: "The student must count backward to find the rhyme and then count forward to learn the pronunciation of the mark” 學者必逆數而知韻之母, 乃順數而知的之音. The decipherment of these spellings was a matter of manipulating numbers. The numerical values of the second spelling pair, corresponding to the position of the characters within the list of their respective rhymes, are also seen in table 8.

In the case of the first spelling pair, Chén was asking the student to "count backward" from 8 to 1 (and find the heading of the rhyme, kuon 1 公), and then "count forward" from there until he reached 5. To do the same with the second spelling pair, the student would count backward from 11 to 1 and then from there back up to 5. In both cases, he would end up with the syllable $t u o \eta_{1}$, which occupied position 5 in the $k u o \eta_{1}$ rhyme. In case the student had not memorized the sequences of characters inside the rhymes well enough to

92. Edwin Hutchins, Cognition in the Wild (Cambridge, Mass.: MIT Press, 1995), 66, 73-78, and 93-116 (examples from the history of navigation); Shigehisa Kuriyama, "Between Mind and Eye: Japanese Anatomy in the Eighteenth Century," in Paths to Asian Medical Knowledge, ed. Charles Leslie and Allan Young (Berkeley and Los Angeles: Univ. of California Press, 1992), 26-27 (examples from the history of medicine).

93. For examples from various cultures, see Georges Ifrah, Histoire universelle des chiffres: L'intelligence des hommes racontée par les nombres et le calcul, second, expanded edition, 2 vols. (Paris: Robert Laffont, 1994), vol. 1, ch. 3 . 

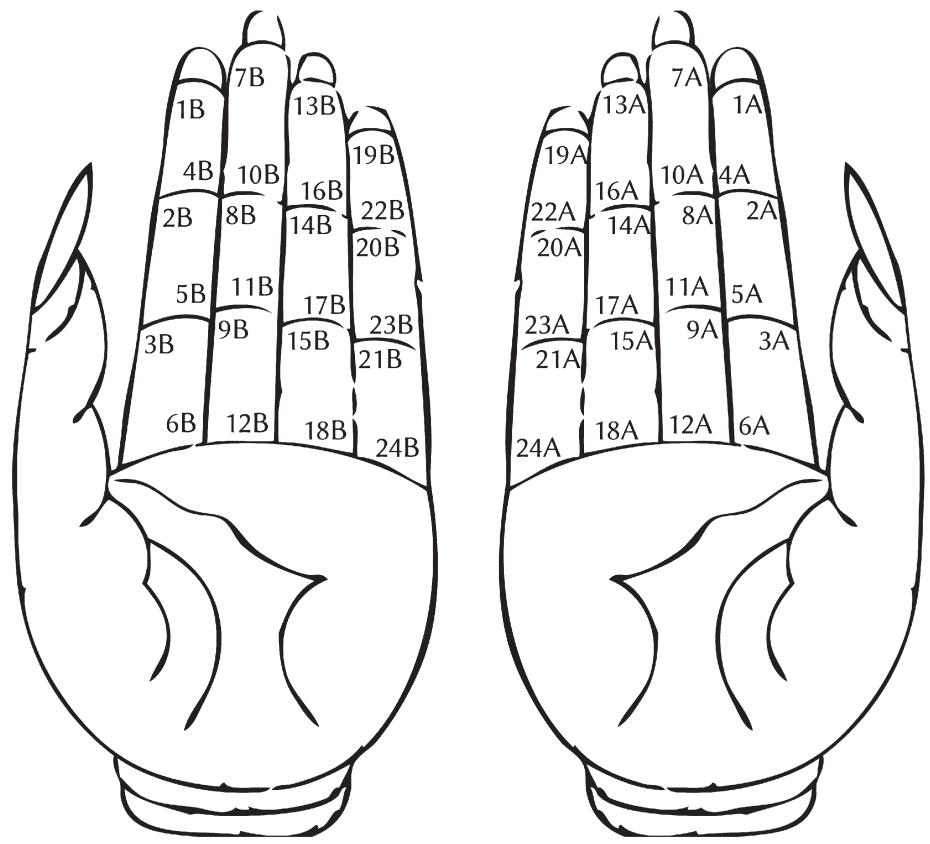

LEGEND:

$1,2,3, \ldots$ 24: Initials

A, B: Rhymes

Each palm contains one rhyme. The syllables in the rhyme each contain the rhyme in question plus one of the twenty-four initials recognized in the book's sound system. ${ }^{\mathrm{h}}$

h. Schematic representation of some aspects of [Chén], Qièyinn méngy̌n, 15b-16a.

FIG. 3. Qièyinn méngy̌̌n's phonological hand diagram

go backward and forward through them using the palms of his hands, he could refer to the printed tables in the book, where he could count back through the characters in the relevant row and then back up again. In sum, Chén did not imagine fănqiè to be an intuitive operation to his students. Commuting phonological properties to numbers, he believed, made it easier.

Hand diagrams, like the game of "shooting characters," involved commuting phonological properties to numbers or positions in a sequence. They also made memorization of initial and rhyme sequences easier by adding a tactile and visual dimension to the learning process. The diagrams could also relieve the practitioner's memory, relying on the positioning of the thumbs to mark phonological properties. Conceivably, the hand diagram's ability to ease the burden on memory could be useful in a game of "shooting characters," yet the focus in Chén's primers was not on playing the game, but teaching the fănqiè method. The character grid that he instructed his readers to project onto their hand did not, as far as I am aware, correspond to the sequences of an actual version of the game.

From the first mentions of "shooting characters" by beating a drum, to the introduction of knocks on cups and finger taps, and finally to the derived usage of the term in rhymetable primers, we have seen the phonological operation behind the game move, as it were, 

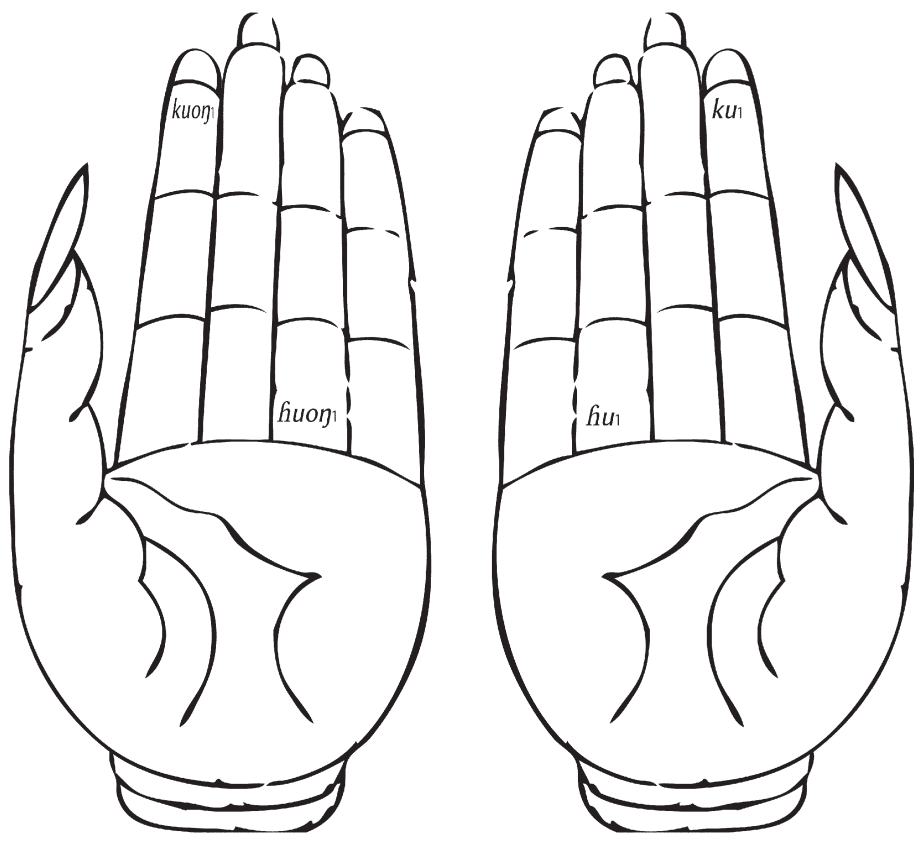

The diagram ${ }^{i}$ spells (the sound system in Chén's book first, followed by contemporary Shāoxìng dialect in brackets and standard Mandarin in parentheses):

$$
\begin{aligned}
& \begin{array}{cccc}
x & y & z & \\
? & h u_{1} \text { 胡 } & d z^{\prime} u o y_{1} \text { 叢 } & \text { huog }_{1} \text { 洪 }
\end{array} \\
& \text { ? }\left[\text { hu } u_{\text {low } 1}\right]+\left[\text { dzoํ }_{\text {low } 1}\right]=\left[\text { ho } \text { low } 1_{1}\right] \\
& \text { (hú) (cóng) (hóng) }
\end{aligned}
$$

The practitioner is verifying the pronunciation of an unknown character ? (x), spelled as $h u_{1}$ (y) plus $d z^{\prime} u o \eta_{1}(z)$. The practitioner knows the pronunciation of the first speller, $y$, as $h u_{1}$, and its belonging in the rhyme $k u_{1}$. He counts through the syllables of that rhyme and finds $h u_{1}$ on position no. 18. He also knows the pronunciation of $z$, as $d z^{\prime} u_{0} \eta_{1}$, and its belonging to the rhyme $k u o \eta_{1}$ 公. He counts to position no. 18 in the rhyme kuon $_{1}$ and learns that $x$ is pronounced huop ${ }_{1}$, without ever having to isolate and positively identify the initial $h$-.

i. Schematic representation of some aspects of [Chén], Qièyīn méngy̌̌n, 15b-16a.

FIG. 4. Qièyinn méngy̌n's phonological hand diagram in use

first from the marketplace to the literary salon, and then to the solitude of the study. In pedagogical presentations, "shooting characters" became a study technique or a way to describe the basics of Chinese phonological analysis. It was never entirely reduced to reading and writing, however: both in the case of using hand diagrams and of moving the fingers along the axes of a grid, "shooting characters" referred to a practical operation that did not belong entirely to the process of reading narrowly defined.

\section{A PHONOLOGICAL CIPHER}

Transporting the game to paper opened new possibilities beside phonological training. Xú Jiàn noted that the method "can transmit any speech sound, which is truly marvelous. How- 
Table 8. Two kinds of fánqiè spellings in Qièyinn méngyǐn

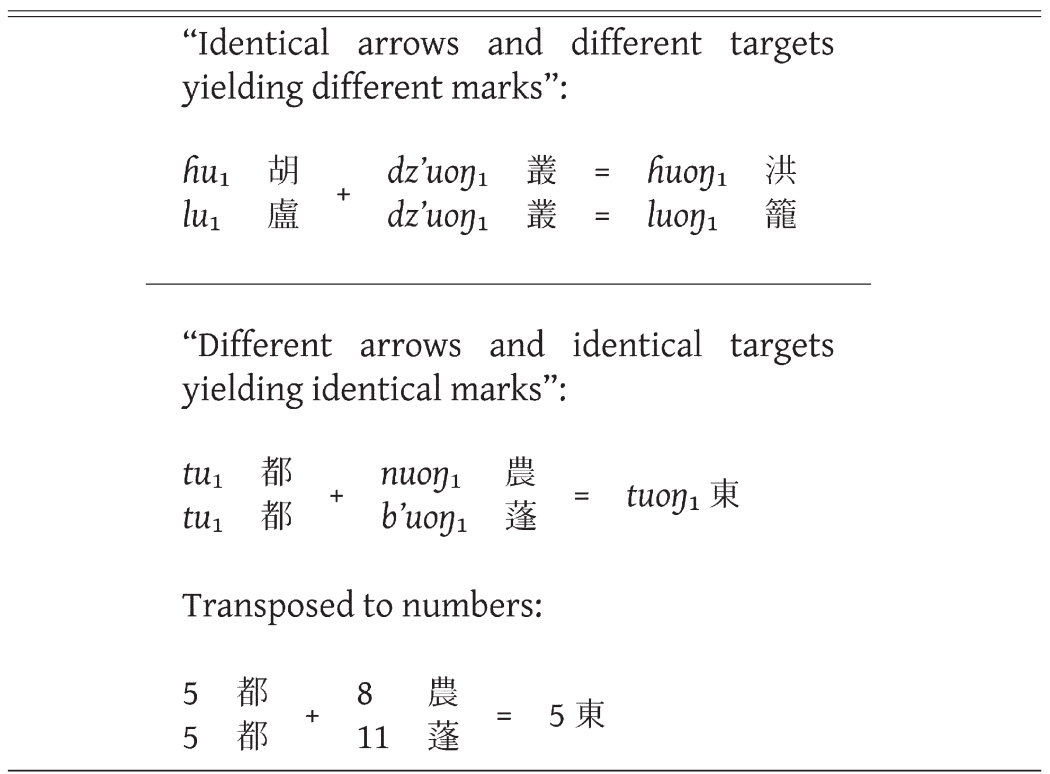

ever, it can only transmit sounds, not their written forms” 凡天下之音, 皆可以傳之, 洵 覺詼詭。然但能傳其音, 不能識其形. Xú presented this as a limitation, but he also made productive use of it. Since Chinese characters represented meaning in addition to sound, the ascription of a character to a syllable transmitted orally by means of the game was always conjectural; several homophonous characters could represent the same syllable. As Xú explained it, if one transmits the sound gōng, "one only learns the sound of $g \bar{o} n g$, and not which one of the [many characters pronounced $g \bar{o} n g]$ that it represents”但知為 $\lceil$ 公」字之 音, 不能辨其為 $\lceil$ 公」, 為「宮」, 為「弓」. This problem was specific to the Chinese writing system; medieval Europeans, who communicated messages by substituting numbers for Roman letters according to their position in the alphabet, and then representing them either on their fingers or in writing, encountered nothing like it. ${ }^{94}$ In late imperial China, in order to avoid conjectures with regards to the written representation of the shot syllable, a notational system was needed that could not be confused with ordinary Chinese writing, in which meaning was encoded alongside sound.

Xú presented several notations. For example, a syllable could be written using the "modern popular numerals" (shìsú hàomă 世俗號馬) commonly used in Chinese markets and by other phonologists before Xú. According to the sequences and their order as used in Xú's book, the syllable tiān could be written $12-5-1+\| \cdot \gamma \cdot 1$, where the first number indicated the final (jiān 奸), the second the initial (tiān), and the last the tone (level tone). Xú did not stop there. He also proposed that "Western [numerical] characters, which can nowadays be seen on many clocks and foreign coins” 西洋之字，今鐘表、番錢上多有書之者也 could be used instead. ${ }^{95}$ Other writers suggested additional notations. Lín Běnyù noted that the

94. Jean-Gabriel Lemoine, "Les anciens procédés de calcul sur les doigts en Orient et en Occident," Revue des études islamiques 6 (1932): 46-47; Ifrah, Histoire universelle des chiffres, vol. 1, 141.

95. Xú, Yīnfū, 3b-4a (shooting of tiān), [yúlùn]:21b-23a (numbers). On the numeral system, see Qǔ, Zhōngguó mínjiàn mìmì yŭ, 172-73. 
shorthand characters used in musical notation for the zither could represent both numbers and names of phonological categories. ${ }^{96}$ Lù Lǒngqí presented a notation based on the "trigrams and lines of the Change classic" (Yìjīng guà yáo 易經卦爻). The number of lines indicated how the reader should move through the book's tables to locate a character. ${ }^{97}$ Hú Yuán, who, as mentioned, used a system of claps and taps, presented a notation that was closer to the game's origins: "When used in correspondence, a clap is marked by a circle, a tap by a dot, and a pause by a blank space” 書札則拍作圈, 點作筆 點, 停頓空一格. 98

Using numerical notations to represent a syllable's location in a sequence or chart was an excellent cipher. Phonological knowledge was in itself arcane. A character in Lǐ Rúzhēn's novel, for instance, managed to insult an unknowing person merely by couching the insult in fănqiè spelling pairs. ${ }^{99}$ Lù Lǒngqí, furthermore, described a “fănqiè letter cipher" 反切 信闇號, called hào tíng 鎬亭 after the two characters used to set off the encoded message from the rest of the text: "Beneath hào, write the text of the letter in fănqiè, and close it using ting. This makes it easy for the reader to grasp the structure”「鎬」字以下寫反切 信文，以「亭」字止。閱者便識眉目. ${ }^{100}$ If the text was not encoded using regular fănqiè, but a numerical notation, even better. Ordinary numerals were one option, ${ }^{101}$ the "modern popular numerals" another. But these were commonly known. Indeed, the market numerals were the opposite of secret; the numbers were explained in standard mathematical textbooks. ${ }^{102}$ Before the publication of Xú Jiàn's book, Lǐ Rúzhēn had used them as to create a numerical phonological notation simply “to make reading easier” 以便觀覽. ${ }^{103}$ Indeed, as Xú wrote, “if the [Western-style Arabic numerals] are used in letters, they are even harder than the cipher [of the market numerals] for people to figure out” 若用以代書, 較暗馬尤令人難識. ${ }^{104}$

It was not only the notation used that prevented decipherment. To reconstruct a syllable on the basis of numbers, the reader of an encoded message had to match the numbers to the same sequences or tables that were used to encode it. The tables in printed books were available for anyone to see, but if an idiosyncratic set of tables or way of encoding were devised and shared between confidants, the secrecy would be greater. "In case the number of people familiar with [a given method] grows too large," Lín Běnyù wrote, "two individuals who want to exchange secret messages must establish another method to prevent a third party from divining their meaning” 倘知此 者漸多, 兩人欲有密言, 須另設一法, 能使他人莫 測. There were several ways that one might go about changing the method. Most obviously, perhaps, “one can make changes to the system of shorthand” 可改其省合形制. Another method was to write the numbers in a way that obfuscated the order in which they were to be read. Instead of writing them linearly, one could write them as if carved on a seal or copper coin. In this system, the top, bottom, left, and right sides of the face of the metaphorical coin each contained a number to be read in an order known only to the recipient of the message

96. Gāo, "Děngyīn," "Shēngwè̀" héhuì, xià:86b-87a. According to Gāo, this section is from Lín's book (ibid., fánlì:1b).

97. Lù and Hè, "Děngyùn biàndú," 744.

98. Hú, Gǔ-jīn, Zhōng-wài yīnyùn tōnglì, vol. 4, chuánshēng:3a.

99. Yáng Nàisī 杨耐思, “Fănqiè de miàoyòng” 反切的妙用, Yǔwén xuéxí, no. 6 (1979): 53; Yáng Yìmíng 杨亦鸣, “Cóng yīnyùn xué jiăodù kàn Jinghuā yuán de zhùzuò quán” 从音韵学角度看《镜花缘》的著作权, in Yáng Yiminng zìxuăn jí (1994; Nánjīng: Fènghuáng chūbănshè, 2010), 45.

100. Lù and Hè, "Děngyùn biàndú," 743.

101. Méi, Chóngdìng Măshì děngyīn, vol. 1, chuánxiăng shèzì fă:34b.

102. One numerical system was explained in the textbook studied in Jiři Hudeček, "Mathematical Practice in the Sixteenth-Century Chinese Compilation Suan fa tong zong," European Offroads of Social Science 1 (2010): 4-17.

103. Lì, Ľ̀shì yīnjiàn, 5:11b.

104. Xú, Yīnfū, [yúlùn:]22b. 
(see figure 5). ${ }^{105}$ The order of the characters engraved on coins had not remained constant throughout history, and it was not always obvious, when faced with a new type of coin, in which order one should read them. ${ }^{106}$

In addition to new levels of secrecy, the game of "shooting characters" enabled new kinds of communication. The principles of the game could be relied on for non-written communication in situations where regular speech was not convenient. I already mentioned Zhōu Jǔ's knocking on a bowl to communicate orders to his servant. An anonymous and undated manuscript, cited previously, similarly noted that the method could be used to "transmit messages next door by knocking on the wall” 隔壁敲語. ${ }^{107}$ Méi Jiàn reported Mă Ziyuán as saying:

The reason that I wrote [my book] was not only to facilitate the spelling of characters. It was more generally with regards to the many [types of] secret messages, which, when transmitted using sounds that the listener records while counting their number, can all be deciphered if one knows how to shoot characters.

槃什氏曰: 『余所纂「等音』一書, 不獨便於切字, 凡對眾隱語皆以響傳之, 聽者記傳 響多寡之數，即能射字而得其語。108

\section{THE GAME AND THE MILITARY}

Transmitting messages by numbers of sounds allowed not just for secrecy, but also for communicating rapidly across great distances. Naturally, "sending a letter" with a written encoded message "using only numbers" could cover potentially unlimited distances of "a thousand $l i ̌$." In Mă's opinion, it was a safe way of communicating: "Other people will not be able to divine the contents from looking at it” 千里寄書, 只用 數目。他人莫能窅測. There were also other methods: "If one uses a drum to transmit the sounds, then communication is possible across several $l i z$; if one uses cannon shots, then it is possible across several hundreds of $l \grave{l}$ ' 若以鼓傳響, 則數里可以通語。以炮傳響, 則百里可以通語. The latter method presented the rare possibility of communication across enemy lines in battle: "If [our forces] are separated by the enemy, then cannon shot can be used to transmit military information” 再若敵人相隔, 以炮聲傳軍情. ${ }^{109}$ More generally, according to Hú Yín, "secret matters of military strategy cannot easily be discussed face to face, they necessitate the method of “transmitting sound like echoes in an empty valley'” 軍機秘密要事難欲對 談, 須用空谷傳聲之法. ${ }^{110}$

It has, indeed, been proposed that the Chinese military made use of a variant of the game. The most ambitious assertion, that the military used it to communicate along the lines of Mă Ziyuán's suggestion, cannot be sustained by the evidence currently available. However, some circumstances lend support to the more modest assertion that the game was used to facilitate the acquisition of local languages by extraprovincial troops.

The site for the purported military use of the game is Fújiàn, a strategically important southeastern province with a strongly divergent local language. Several writers have suggested that

105. Gāo, "Děngyīn,” "Shēngwèi” héhuì, xià:87b-88a (491).

106. Lyce Jankowski, "Era Name and Power Regalia in Song Coinage" (paper presented at the 21st Biennial Conference of the European Association for Chinese Studies, Saint Petersburg, August 27, 2016). Scholars in the Qing period occasionally came across old coins with indecipherable foreign writing (Imre Galambos, Translating Chinese Tradition and Teaching Tangut Culture: Manuscripts and Printed Books from Khara-khoto [Berlin: De Gruyter, 2015], 56-57), but there is no evidence of such discoveries playing a part in this case.

107. Fānqiè zhǐzhăng, 1522.

108. Méi, Chóngdìng Măshì děngyīn, vol. 1, chuánxiăng shèzì fă:32a.

109. Gāo, "Děngyīn," "Shēngwèi”" héhuì, xià:82a. Cf. Méi, Chóngdìng Măshì děngyīn, vol. 1, chuánxiăng shèzì fă:32a, which does not contain this latter statement.

110. Hú, Qièyīn qǔméng, 7b. 


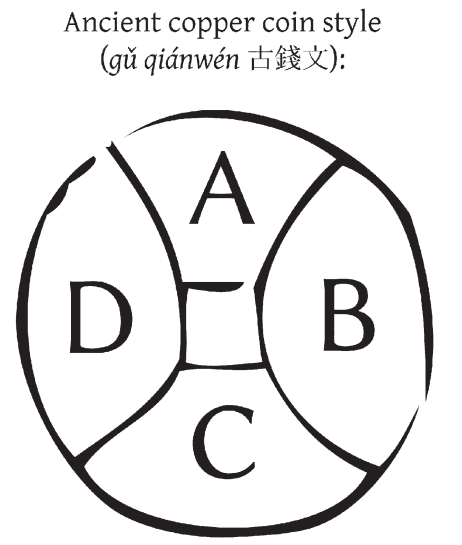

\section{Modern copper coin style (jin qiánwén 今錢文):}

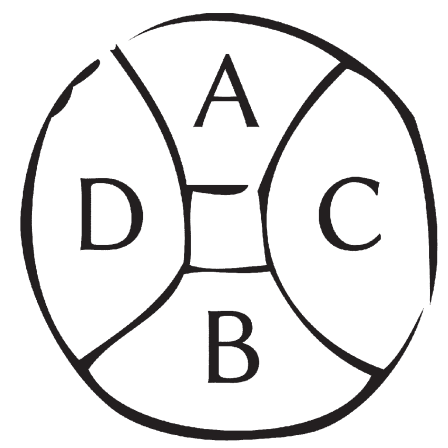

\author{
LEGEND: \\ A: Tone (shēng 聲) \\ B: Call (yin 音) \\ C: Rhyme (yùn 韻) \\ D: Initial (mǔ 母)
}

Syllables are to be deciphered in the alphabetical order of the letters: tone first, then call, then final, and then initial. When used to note syllables, a number would stand in the place of each letter, corresponding to series of finals, initials, etc., known to the recipient. ${ }^{j}$

j. Adapted from Gāo, "Děngyīn," "Shēngwèi” héhuì, xià:88a (491; not to scale). The translation of Lín's term yīn as "call” is based on Zhào Yīntáng 趙蔭棠, Děngyùn yuánliú 等韻源流 (Shànghăi: Shāngwù Yìnshūguăn, 1957), 284, where Lín's five yīn are identified as a development out of the common “four calls" (sìhü 四呼).

FIG. 5. Illustration of a coin-shaped phonological cipher

the game of shooting characters was used to transmit coded messages in the army there. Their reference is usually the book Qì cānjūn bāyīn zìỳ̀ biànlăn 戚參軍八音字義便覽 (Adjutant Qì's convenient reader for character meanings distributed according to the eight tones; c. 1600). ${ }^{111}$ This phonological dictionary was named after Qì Jiguāng 戚繼光 (1528-1588), ${ }^{112}$ a military commander from the north who achieved hero status in Fújiàn following his success in fighting pirates. Qì had nothing to do with the book, yet it has been proposed, based only on the possibly eighteenth-century ascription of Qì's name, that the military man and phonologist Chén Dì 陳第 (1541-1617), who worked for Qì in Fújiàn, ${ }^{113}$ or someone in his entourage, wrote it. ${ }^{114}$ The book contains a description of the character-shooting method, as well as an early mention of a fănqiè game (literally sòuy̌̌ 嗽語, “coughed words,” but reportedly with

111. Yáng, "Fănqiè de miàoyòng," 52; Liú and Lǔ, "Shèzì yóuxì jíqí yìngyòng," 160.

112. Chaoying Fang and J. F. Millinger, "Ch'i Chi-kuang," in Dictionary of Ming Biography, 1368-1644, ed. L. Carrington Goodrich and Chaoying Fang, vol. 1 (New York: Columbia Univ. Press, 1976), 220-24.

113. Chaoying Fang, "Ch'en Ti," in Goodrich and Fang, Dictionary of Ming Biography, vol. 1, 108-84.

114. Luó Chángpéi 罗常培, “Xiàmén yīnxì”厦门音系, in Luó Chángpéi wénjí, vol. 1 (1956; Jĩnán: Shāndōng jiàoyù chūbănshè, 2008), 67; editors’ preface in Lí Rúlóng 李如龍 and Wáng Shēngkuí 王升鬼斗, eds., “Qì, Lín bā yīn” jiào zhù 戚林八音校注, typeset, critical edition (Fúzhōu: Fújiàn rénmín chūbănshè, 2001), 1-3. 
the meaning "secret words") ${ }^{115}$ of the type later attested in oral use and mentioned above. However, there is no indication in the text that it should be used as code, nor are there any references to the military. A connection between the character-shooting method and the military might still have existed. Rather than being used to communicate by cannon shot, Qì cānjūn bāyīn zìỳ biànlăn would have been compiled to teach the troops a local language. ${ }^{116}$ This more modest claim is plausible, if not for any reason connected to the title ascribing it to Qì. Rather, it is suggested by the booklet Pāizhăng zhīshēng qièyīn diào píngzè tú 拍掌知声切 音調平大圖 (Chart for learning the initial, spelling the rhyme, and circling through the even and oblique tones by clapping; c. 1680s). ${ }^{117}$ This graded rhyme table, which described a local dialect, was written Liào Lúnji 廖綸璣 (fl. 1670-80s [?]), of Guăngdōng, who probably came to Fújiàn as an education officer for the Manchu army in the late seventeenth century. ${ }^{118}$ Liào was a dedicated teacher, and the purpose of his booklet clearly educational. The päizhăng, "clapping," of the title suggests that its charts were to be studied, presumably by the newly arrived troops, using character-shooting techniques.

\section{THE GAME AND POPULAR EDUCATION}

Using the phonological game to teach students to use a graded rhyme table, discussed previously, taught them first and foremost the principles on which the game itself was based. By contrast, teaching soldiers a new language by pairing syllables from phonological jingles, if ever actually practiced, was an example of using a derivative of the game to an educational end that lay outside phonology proper. There is evidence that the game also inspired a much more radical educational program.

Fújiàn native Huáng Qiān's 黃謙 (fl. mid-1790s) ${ }^{119}$ phonological dictionary, like several others, used a numerical notation to represent syllables as aggregates of the phonological properties of initial, final, and tone. Scholars have, with good reason, considered Huáng's book a continuation of the Fújiànese tradition of phonological works that promulgated the character-shooting method under the names of "clapping" or "learning the pronunciation by striking a piece of wood” (jī mù zhī yīn 擊木知音). ${ }^{120}$ Whereas a numerical notation for some writers represented either a way to transport the phonological game to paper, or a cipher intended to make reading more difficult, Huáng, like Lǐ Rúzhēn, saw in it a tool for making reading and writing easier for the less educated. Before the book's completion, Huáng reported that a guest had suggested that it might

guide [the reader] to the characters by following the sound and enable the peasants, workers, and merchants to further their knowledge only by using the book, sparing them the burden of "providing [food] and drink in return for writing instruction" [i.e., paying tuition for classes].

因音以識字, 使農工商賈按卷而稽, 無事載酒問字之勞。

115. Lí and Wáng, “Qì, Lín bā yīn” jiào zhù, no continuous pagination; Huáng Wēi 黄薇, “Míng-Qīng wǔ zhǒng yùnshū zhōng de shèzì fă” 明清五种韵书中的射字法, Dàqìng Shīfàn Xuéyuàn xuébào 33, no. 1 (2013): 110.

116. Lǐ, Hànyǔ děngyùn xué, 349.

117. Liào Lúnjī 廖綸璣, “Liào Lúnjī Pāizhăng zhīyīn yǐngyìn běn” 廖綸璣《拍掌知音》影印本, ed. Fāngyán Biānjí Bù, probably written sometime between 1670 and 1700, Fāngyán, no. 2 (1979): 143-54.

118. Furuya Akihiro 古屋昭弘 [Gǔwū Zhāohóng], "Guānyú Pāizhăng zhīyīn de chéngshū shíjiān wèntî” 关于 《拍掌知音》的成书时间问题, Zhōngguó yǔwén, no. 6 (1994): 452-53.

119. Zhōu Chángjí 周长楫, “Lüè tán difāng yùnshū Huìyinn miàowù” 略谈地方韵书《彙音妙悟》, Císhū yánjiū, no. 6 (1982): 111; Huáng Diănchéng 黄典诚, “Quánzhōu Huìyinn miàowù shùpíng” 泉州《菓音妙悟》述 评, in Huáng Diǎnchéng yǔyán xué lùnwén jí (1980; Xiàmén: Xiàmén Dàxué chūbănshè, 2003), 250 (incl. note 2 [place of origin]).

120. Hóng Wéirén 洪惟仁, Quánzhōu fāngyán yùnshū sān zhǒng 泉州方言韻書三種 (Táiběi: Wǔlíng chūbănshè, 1993), 31. 
Huáng agreed, and compiled a book that "contained both vernacular characters and local pronunciations" 俗字、土音皆載. ${ }^{2} 21$

Huáng's book proposed a new notational system. He did not mention the game of "shooting characters," but he followed its principles. His system was similar to the market-numeral notations and the zither-notation cipher that the shèzì theorists Lǐ Rúzhēn, Xú Jiàn, and Lín Běnyù described. Huáng's spelled one syllable using three numbers, representing, respectively, the rhyme, the initial, and the tone, in that order. The numbers, as usual, referred to positions in series that each listed one of these three phonological properties. The numbers were written using a system of shorthand ("new numerals" [xīnshù 新數]) of, as far as I am aware, Huáng's own invention, that used one or a few strokes taken from Chinese characters. Any syllable could thereby be represented using a few strokes of the brush.

The radical character of Huáng's book lay in the educational use that he suggested for the new system, which he called “quickly acquired three-step notation”三推易識字樣:

In shops, this book might be placed on the bench, for the benefit of apprentices and others who, while writing, might forget how to trace a character. If they consult the book, they can avoid mistakes arising from the writing of a [homophonous] character [in the place of the one of which they forgot the tracing], as well as save themselves the trouble of asking about it.

是書凡在店舖者, 或學業未深, 或舉筆忘字, 置之座上。閱之便無別字之錯, 亦免問字 之勞。122

Huáng proposed that individuals primarily interested in the functional literacy needed in the trades could use his three-step notation to represent the sound of words for which they had forgotten the characters. He believed that this method was better than writing a different character in its place and having the reader infer which word was meant. Merchants and clerks could thereby avoid confusion and save time, perhaps also by learning only a smaller number of characters.

Huáng's educational program was highly original for proposing a supposedly simple notation and encouraging its use among individuals with sub-elite literacy. It makes him stand out both among theorizers of the game of "shooting characters" and among phonologists overall. His system was not, however, an alphabet in the sense of a script representing subsyllabic sounds by using graphs whose order on the page tends toward imitation of the order of their articulation in speech. ${ }^{123}$ In Huáng's notation, the final (confusingly, for us today, called zìmǔ) preceded the initial. He stated it explicitly: "First, begin with the final on top, the spelled sound [i.e., the initial] receives it on the [lower] left” 先從字母升于頭, 反切聲音 左位收, where top and left refers to the position of the respective numbers in the triangle that constituted a written syllable. ${ }^{124}$ Furthermore, the characters that Huáng used to represent initials and rhymes did not, as in the better-known spelling reform proposals of his day, to

121. Huáng Qiān, “Xiáng zhù Huìyīn miàowù” 詳註彙音妙悟, in Hóng, Quánzhōu fāngyán yùnshū sān zhǒng (1903), facsimile of a xylograph with a preface dated 1800, xù:2b. I am quoting from the only complete edition available to me. A survey of the other editions is found in Wáng Jiànshè 王建设, "Xīn fāxiàn de Huìyīn miàowù bănběn jièshào” 新发现的《彙音妙悟》版本介绍, Zhōngguó yǔwén, no. 3 (2001): 263-66. See also Huáng, "Quánzhōu Huìyinn miàowù shùpíng," 261 (incl. note 1).

122. Huáng, "Xiáng zhù Huìyīn miàowù," sān tuī yìshí zìyàng:3b.

123. In other words, it did not "pair sounds" 拼音, pace Huáng Diănchéng 黄典诚, “Huáng Qiān de "sān tuī chéngzì fă'” 黃謙的《三推成字法》, Wénzì găigé, no. 10 (1957): 42; [Huáng Diănchéng 黄典诚?], "Mǐnnán dìqū de fāngyán yùnshū” 闽南地区的方言韵书, in Xiàmén huàwén, ed. Xǔ Cháng’ān and Lǐ Xītài (Fúzhōu: Lùjiāng chūbănshè, 1993), 19.

124. The tone followed, lastly, on the lower right: Huáng, "Xiáng zhù Huìyīn miàowù," sān tuī xīn shùfă:5a. 
the greatest extent possible represent syllables that were, respectively, open (for initials) or had a zero initial (for finals). ${ }^{125}$

The users of Huáng's notation system could, then, not read the numbers in succession and approximate the intended syllable, but had to abstract first the rhyme from the top number, then the initial from the one at the lower left, and finally the tone from the number on the lower right, before they could reconstruct the intended syllable. This procedure required as much phonological training as the other versions of "shooting characters." Its application in practice might thus have been restricted, but many communities included individuals who would easily have grasped these principles. Several of the popular, fănqiè-like secret languages that flourished in parts of China used a similar method, whereby the rhyme was put before the initial. The folklorist and historian Gù Jiégāng 顧頡剛 (1893-1980) as a child overheard blind Daoist practitioners, invited to the family home for a religious ceremony, use such a language between themselves, and young Gù later taught it to his classmates. ${ }^{126}$

\section{CONCLUSION}

This paper has treated the phonological game of "shooting characters" and its various uses as attested in late imperial sources. The game appears to have originated as a way to show off phonological proficiency in a festive setting, if not also for learning phonology. At some point, its development intersected with other learning aids, such as hand mnemonics and arguably even the graded rhyme tables themselves, and became a description of pairing things other than words (numbers; axes of a grid; characters written on the palm-side of the fingers) to form syllables. Scholars theorized, and perhaps also used, the principles behind the game to transmit encoded messages either in writing or acoustically, by using drums or cannon. Yet encoding messages was not necessarily intended to make them harder to read; at least one writer believed that the code could make reading and writing easier.

During the centuries following its earliest mentions, the game acquired many uses in a variety of contexts. It was not, of course, ever used by Confucius, as Lù Lǒngqí claimed, nor did it have anything to do with the telegraph. Yet the principle of converting speech sounds to numbers in order to transmit them over great distances was indeed common to these two otherwise so different linguistic technologies. Even if the proposals to communicate across dozens of kilometers by "shooting characters" through a cannon remained unrealized, Hú Yín's reference to the telegraph has merit. The story of the phonological game related in these pages suggests that Chinese phonology involved more than books, and might have relevance far beyond the history of the Chinese language.

125. Mårten Söderblom Saarela, "Alphabets avant la lettre: Phonographic Experiments in Late Imperial China," Twentieth-Century China 41.3 (2016): 234-57.

126. Gù in Róng Zhàozǔ 容肇祖, “Fănqiè de mìmì yǔ” 反切的秘密語, Gêyáo zhōukān, no. 52 (1924): 2. 